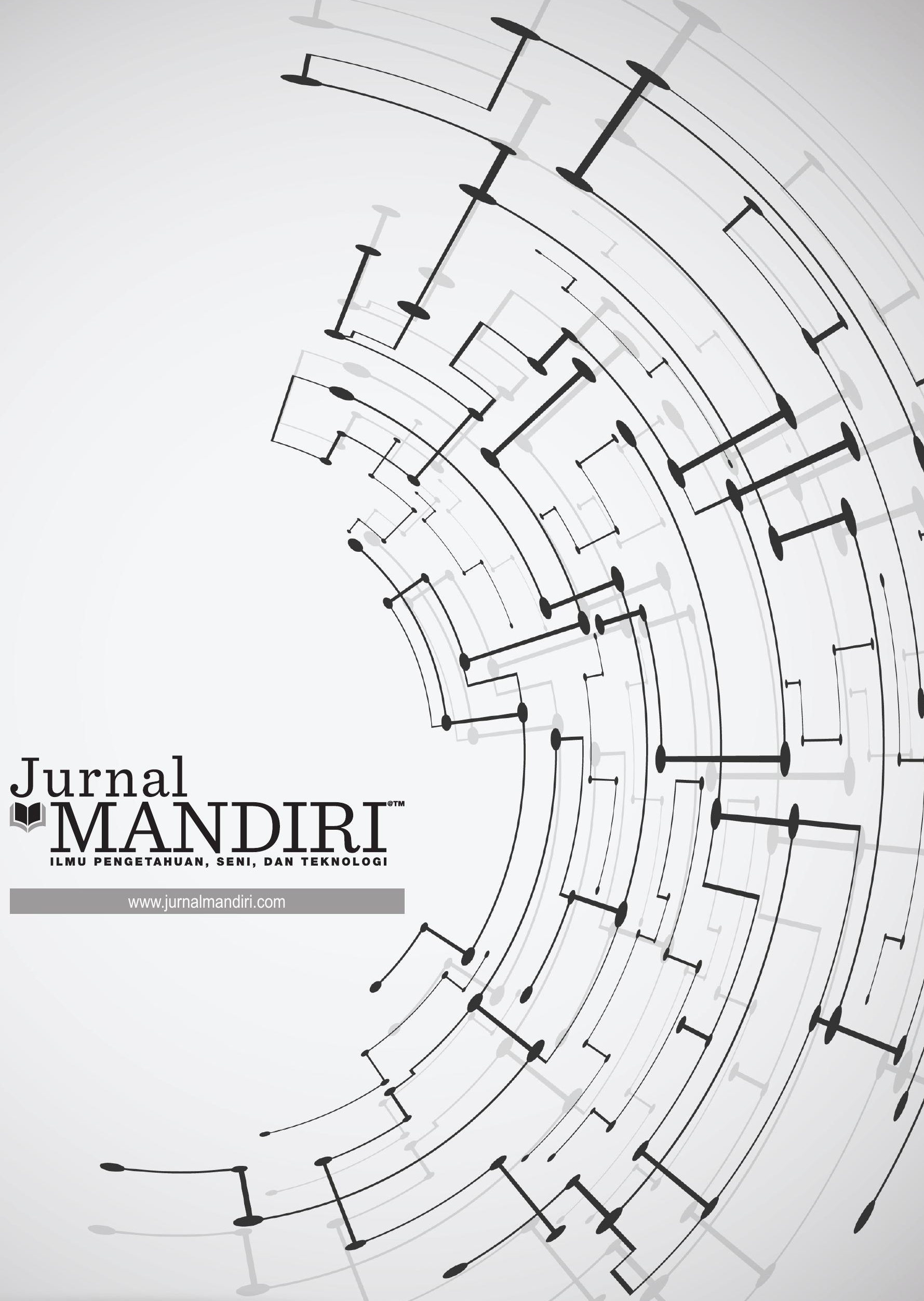


ISSN : 2580-3220, E-ISSN : 2580-4588

J. Mandiri., Vol. 3, No. 1, Juni 2019 (132 - 149)

(C)2018 Lembaga Kajian Demokrasi

dan Pemberdayaan Masyarakat (LKD-PM)

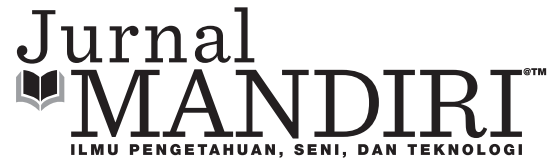

\title{
ANALISIS TINGKAT KEPUASAN PELANGGAN TERHADAP MODEL BISNIS PLATFORM OJEK ONLINE
}

\author{
Nefo Indra Nizar \\ Fakultas Ekonomi, Universitas Pamulang \\ nefoindra@gmail.com
}

\begin{abstract}
Abstrak
Model bisnis platform saat ini sedang menjadi perhatian, karena dengan cepat menjadi alat baru di dalam strategi bisnis sebagai tempat untuk membentuk ekosistem, sehingga lebih mudah untuk memenuhi dari dua sisi, yaitu permintaan dan pasokan. Di Indonesia model bisnis platform berbasis transportasi online sudah berjalan, bahkan salah satu perusahaan ojek online sudah memiliki aset di atas 1 miliar dolar dan dijuluki perusahaan unicorn. Dari sisi permintaan ojek online dituntut dapat memberikan alternatif solusi terhadap sistem transportasi yang ada, yang pada gilirannya adalah memberikan tingkat kepuasan kepada pelanggan ojek online. Tujuan dari penelitian ini adalah untuk mengetahui faktor-faktor apa saja yang mempengaruhi tingkat kepuasan pelanggan. Diidentifikasi ada lima faktor yang mempengaruhi tingkat kepuasan pelanggan, yaitu: keamanan dan kenyamanan $\left(X_{1}\right)$; pelayanan $\left(X_{2}\right)$; ketepatan waktu $\left(X_{3}\right)$; kemudahan pemesanan $\left(X_{4}\right)$ dan kesesuaian harga $\left(X_{5}\right)$. Metode penelitian menggunakan metode kuantitatif dengan pendekatan analisis regresi berganda untuk mengetahui faktor-faktor tersebut terhadap kepuasan pelanggan (Y). Berdasarkan uji statistik, secara parsial (uji t) di dapat hasil bahwa faktor kesesuaian harga $\left(X_{5}\right)$ berpengaruh nyata terhadap tingkat kepuasan pelanggan (Y). Sementara secara bersama-sama (uji F), faktor keamanan dan kenyamanan, pelayanan, ketepatan waktu, kemudahan pemesanan, dan kesesuaian harga berpengaruh nyata terhadap tingkat kepuasan model bisnis platform ojek online.
\end{abstract}

Kata Kunci : Tingkat Kepuasan, Model Bisnis, Platform, Ojek Online

\begin{abstract}
The platform business model is currently becoming a concern, because it is quickly becoming a new tool in business strategy as a place to form ecosystems, making it easier to meet both sides, namely demand and supply. In Indonesia the online transportation-based platform business model is already underway, even one of the online motorcycle taxi companies already has assets in excess of 1 billion dollars and is known as a Unicorn company. In terms of demand for ojek online, it is required to provide alternative solutions to existing transportation systems, which in turn will provide satisfaction to online motorcycle taxi customers. The purpose of this study is to find out what factors influence the level of customer satisfaction. There were identified five factors that influence the level of customer satisfaction, namely: security and convenience $\left(X_{1}\right)$; service $\left(X_{2}\right)$; timeliness $\left(X_{3}\right)$; ease of ordering $\left(X_{4}\right)$ and price suitability $\left(X_{5}\right)$. The research method uses quantitative methods with multiple regression analysis approach to find out these factors to customer satisfaction (Y). Based on
\end{abstract}


statistical tests, partially ( $t$ test) can be obtained that the price suitability factor $\left(X_{5}\right)$ has a significant effect on the level of customer satisfaction $(Y)$. While together ( $F$ test), safety factors and comfort, service, timeliness, ease of ordering, and price suitability have a significant effect on the level of satisfaction of the online motorcycle taxi platform business model.

Keywords : Satisfaction Level, Business Model, Platform, Online Motorcycle Taxi

\section{PENDAHULUAN}

\section{Latar Belakang}

Simon (2014), mendefinisikan platform sebagai sebuah ekosistem yang sangat berharga dan berpengaruh yang dapat dengan cepat dan mudah mengukur, mengubah, dan menggabungkan fitur-fitur baru, pengguna, konsumen, vendor dan rekanan. Saat ini platform terkuat ditanamkan dalam teknologi yang sama kuatnya, serta penggunaannya yang cerdas. Dengan kata lain platform-platform ini tidak didasarkan pada aset fisik, lahan, dan sumber daya alam.

Profesor Andrei Hagiu (2016) memberikan pengertian Model Bisnis Platform, atau sering juga disebut dengan istilah platform multi-sisi (multi sided platform) adalah teknologi, produk atau layanan yang menciptakan nilai terutama dengan memungkinkan interaksi langsung antara dua atau lebih kelompok pelanggan atau peserta. Selanjutnya Simon (2014), menjabarkan bagaimana platform sebagai sebuah model bisnis, yaitu platform yang dapat menghasilkan pendapatan dan keuntungan yang digambarkan secara visual pada gambar 1 di bawah.

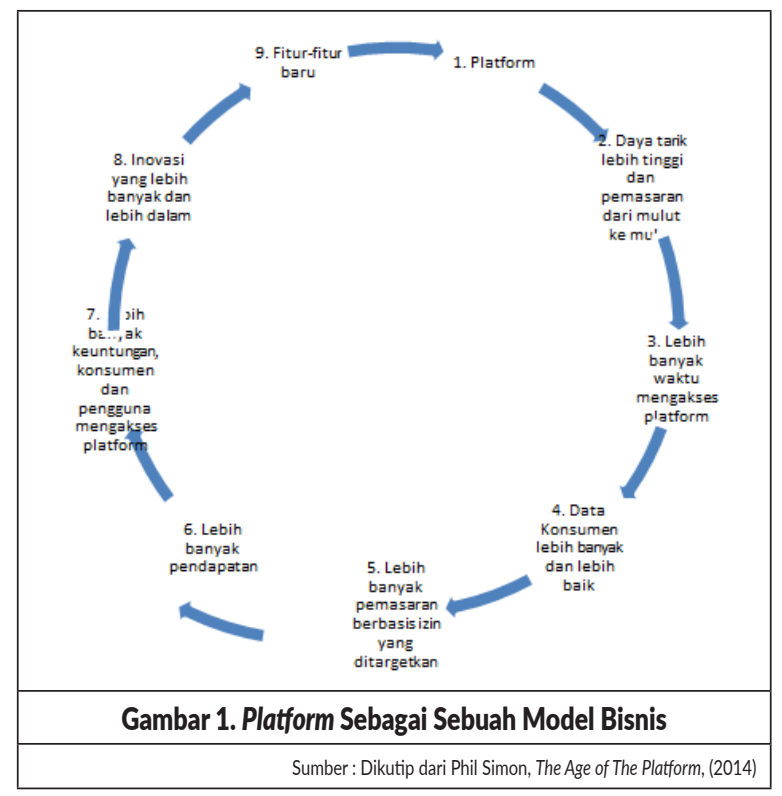

Kim (2015) di dalam penelitiannya menyebutkan teori-teori akademik menyangkut strategi platform yang meliputi: pasar dua sisi, efek jaringan, dan ekosistem bisnis. Singkatnya, model bisnis platform cenderung melibatkan transaksi yang terjadi dalam pasar dua sisi yang meliputi adanya komponen, aturan, dan dua sisi. Efek jaringan muncul dari transaksi ini karena transaksi di pasar dua sisi menciptakan nilai dengan memfasilitasi interaksi antara pihak yang berbeda. Terlebih lagi, efek jaringan ini menciptakan ekosistem bisnis, dan inovasi muncul dari ekosistem bisnis. Oleh karena itu, definisi model bisnis selaras dengan terjadinya transaksi, efek jaringan, ekosistem bisnis, dan inovasi secara berurutan (lihat Gambar 2).

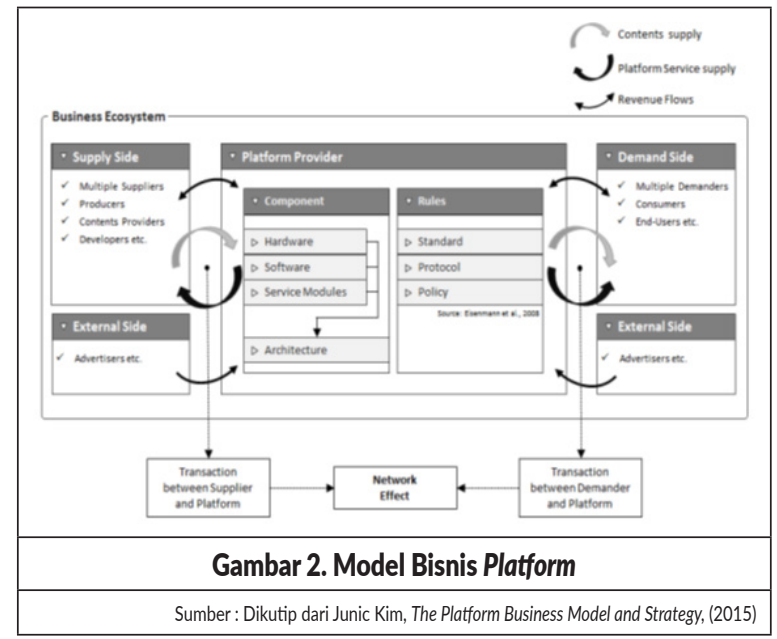

Platform dan model bisnis platform saat ini sedang dalam sorotan karena mereka dengan cepat menjadi alat baru strategi bisnis sebagai tempat untuk membentuk ekosistem, sehingga lebih mudah untuk memenuhi permintaan dan pasokan. Ini muncul sebagai elemen penting dari daya saing ekosistem perusahaan. Platform adalah kumpulan solusi oleh saluran akses atau antarmuka yang terkait dengan masalah entitas yang dimiliki ekosistem. Sebuah platform di- 
pahami sebagai sesuatu yang memungkinkan peserta lain dalam suatu ekosistem untuk membangun barang, layanan, atau teknologi yang saling melengkapi berdasarkan pada fondasi terintegrasi barang, layanan, dan teknologi (Kim, 2015).

Di Indonesia, bentuk perusahaan dengan model bisnis platform berbasis transportasi yang pertama dan dikenal adalah Gojek Online, kemudian disusul dengan kemunculan Grab dan Uber. Munculnya Gojek Online di Indonesia yang sudah dimulai dirintis tahun 2011 merupakan salah satu alternatif untuk memenuhi kebutuhan masalah transportasi murah di Indonesia.

Pada awal tahun 2015, Nadiem Makarim, lulusan S2 Harvard Business School, kemudian membuat aplikasi Gojek, aplikasi berbasis android yang dipergunakan untuk memudahkan pengojek dan penumpang terhubung dengan aplikasi smartphone Gojek.

Saat ini Gojek sudah menjamur, bahkan bertambah dengan beberapa provider seperti Grab dan Uber. Keberadaannya sangat dirasakan manfaatnya bagi pengguna transportasi, karena selain murah, penggunaan transportasi ini juga sangat mudah, hanya dengan melakukan pemesanan order melalui smartphone, pengguna dapat menggunakan transportasi gojek.

Disisi lain, dari sisi informal, dengan adanya Gojek mampu menyerap tenaga kerja yang tidak sedikit. Pada gilirannya mampu memberikan kontribusi yang nyata terhadap perekonomian Indonesia. Berdasarkan Lembaga Ekonomi dan Bisnis Universitas Indonesia, Gojek berkontribusi Rp8,2 triliun per tahun ke dalam perekonomian Indonesia (http://ekonomi.metrotvnews.com/ analisa-ekonomi/ob3VJ1mN-mengukur-tarifojek-online, di akses tgl 26/09/2018).

Dengan kehadiran transportasi online, telah memberikan kontribusi nyata terhadap perekonomian. Tetapi di sisi lain, perusahaan transportasi berbasis online, saat ini sebagian besar saham dimiliki oleh investor asing. Gojek saat ini merupakan salah satu Unicorn Indonesia, yaitu perusahaan start up yang bernilai di atas USD 1 Miliar, setelah menerima dana dari delapan investor yang dipimpin oleh Sequoia
Capital dan Warburg pada tahun 2016, sehingga memiliki total aset USD 1,75 Miliar (http://www. tribunnews.com, di akses tgl 04 Maret 2019).

Sementara, transportasi ojek online merupakan salah satu alternatif solusi penyediaan sarana transportasi yang cukup diminati oleh masyarakat, mengingat kondisi sistem transportasi yang ada sekarang belum secara optimal memenuhi kebutuhan masyarakat yang memerlukan transportasi umum.

Penggunaan ojek online oleh masyarakat selain karena kondisi fasilitas transportasi massal yang buruk, kondisi jalan yang macet, sementara tingkat mobilitas masyarakat yang tinggi, serta keperluan untuk dapat bergerak dari satu tempat ke tempat lain dengan cepat, tepat dan fleksibel merupakan beberapa faktor yang menyebabkan masyarakat memilih transportasi ojek online dibandingkan dengan alat transportasi yang lain.

Dari sisi model bisnis, platform ojek online perlu memperhatikan 2 sisi, yaitu sisi penawaran dan sisi permintaan. Berdasarkan teori ekonomi mikro, tingkat permintaan suatu komoditas, produk atau jasa dipengaruhi oleh tingkat harga. Apabila harga naik, maka permintaan akan barang dan jasa menurun, sebaliknya apabila harga turun maka permintaan akan barang dan jasa akan meningkat. Teori permintaan ini pada dasarnya diturunkan dari nilai guna, atau preferensi tingkat kepuasan terhadap barang dan jasa yang digunakan.

Berbeda dengan penggunaan ojek online. Tingkat harga sudah ditentukan oleh provider atau perusahaan penyediaan jasa ojek online, seperti perusahaan Gojek, Grab atau Uber. Pengguna jasa transportasi ojek online, cukup memesan ojek online melalui smartphone, mencantumkan asal dan tujuan perjalanan yang ingin dikunjungi, maka tarif transportasi yang harus dibayar sudah langsung muncul di smartphone.

Permintaan terhadap penggunaan ojek online tidak dipengaruhi oleh faktor tarif atau harga dari ojek online, tetapi lebih dipengaruhi oleh faktor non-harga. Demikian juga dengan tingkat kepuasan konsumen juga tidak dipengaruhi oleh tingkat harga, tetapi lebih dipengaruhi oleh persepsi harga. Harga atau tarif ojek online 
merupakan hal yang given-sudah ditentukan.

Menurut Rangkuti (2013), tingkat kepuasan pelanggan berjalan berbarengan dengan ketidakpuasan. Artinya respons pelanggan terhadap evaluasi dan ketidaksesuaian yang dirasakan antara harapan sebelumnya dan kinerja aktual produk/jasa yang dirasakan setelah pemakaiannya. Jadi kepuasan adalah suatu tanggapan emosional yang dirasakan oleh pelanggan pada saat mereka menikmati pengalaman menggunakan atau merasakan produk dan jasa.

\section{Model Bisnis Platform}

Menurut Kim (2015) dari sudut pandang ekonomi, model bisnis platform terdiri dari tiga konsep teoretis: pasar dua sisi, efek jaringan, dan ekosistem bisnis. Konsep model bisnis platform lebih jelas dipaparkan oleh Uenlue (2017) yang menjelaskan bahwa di dalam bisnis model platform dapat dibedakan berdasarkan sisi penawaran yang merupakan pemasok layanan platform untuk kebutuhan platform dan sisi permintaan sebagai pengguna platform. Selanjutya Uenlue (2017) mencoba mengelompokkan bisnis platform seperti gambar 3 di bawah. Salah satu model bisnis platform adalah UBER yang merupakan model bisnis platform berbasis transportasi online.

Selanjutnya Uenloe (2017) membagi efek jaringan menjadi dua, yaitu efek jaringan langsung dan efek jaringan tidak langsung. Efek jaringan langsung adalah meningkatnya nilai jaringan karena meningkatnya jumlah pengguna. Pada efek jaringan langsung ini biasanya terjadi pada platform media sosial.Efekjaringan tidaklangsung adalah efek dari satu jenis peserta pada jenis peserta lainnya. Contohnya adalah pada platform Uber. Pengemudi dan penumpang berada di sisi platform yang berbeda. Uber akan menciptakan nilai yang sangat kecil untuk seorang penumpang jika hampir tidak ada pengemudi. Waktu menunggu akan sangat panjang. Sama halnya, untuk pengemudi, platform akan memiliki nilai kecil tanpa jumlah pengendara yang memadai. Waktu idle untuk driver akan membuat render platform bernilai kecil. Nilai jaringan meningkat dengan jumlah peserta lintas-sisi (partisipasi).

Model bisnis platform menghubungkan banyak sisi (kelompok peserta yang independen) satu sama lain. Ini menciptakan efek jaringan langsung dan tidak langsung. Mereka sangat penting untuk pertumbuhan dan penciptaan nilai platform untuk para pesertanya

James F. Moore dalam Kim (2015) menyebutkan bahwa ekosistem bisnis adalah 'komunitas ekonomi yang didukung oleh fondasi organisasi dan individu yang saling berinteraksi, organisme dari dunia bisnis.' Dengan kata lain, Moore memberikan definisi tentang 'ekosistem persaingan'; logika utama ekosistem bisnis adalah studi tentang hubungan timbal balik antara perusahaan dan lingkungan bisnis di sekitarnya, seperti dalam lingkungan biologis, "bisnis ekologi adalah hubungan antara bisnis dan lingkungannya". Tujuan penting dari ekologi bisnis adalah konsistensi antara sinkronisasi ekologi dan kombinasi bisnis di bawah situs yang digunakan dan mempengaruhi. Dalam ekosistem bisnis, perusahaan menempati posisi yang benar, seperti halnya spesies ekologis dalam ekosistem alami, dan berbagai pemangku kepentingan dalam ekosistem berevolusi dan menyejajarkan diri dengan pemangku kepentingan lain di platform.

Uenloe (2018) secara baik menjelaskan model bisnis platform transportasi online, dengan mengambil contoh model bisnis Uber. Berdasarkan analisis model bisnis kanvas, model bisnis dibagi menjadi sembilan komponen, seperti yang disarikan pada tabel di bawah:

\begin{tabular}{|c|c|c|}
\hline \multicolumn{3}{|c|}{ Tabel 1. Model Bisnis Canvas Transportasi Online (Uber) } \\
\hline $\begin{array}{l}\text { 1. MITRA UTAMA } \\
\text { a. Pengemudi } \\
\text { b. Teknologi } \\
\text { c. Investor }\end{array}$ & $\begin{array}{l}\text { 2. KEGIATAN UTAMA } \\
\text { a. Meningkatkan efek } \\
\text { jaringan (mencapai } \\
\text { keunggulan kompetitif) } \\
\text { b. Mengurangi waktu idle } \\
\text { pengemudi dan waktu } \\
\text { tunggu pelanggan } \\
\text { c. Mengajak lebih banyak } \\
\text { lagi peserta untuk } \\
\text { bergabung } \\
\text { d. Meningkatkan proposisi } \\
\text { nilai } \\
\text { e. Mempermudah pembi- } \\
\text { ayaan kendaraan } \\
\text { f. Memperluas opera- } \\
\text { sional transportasi } \\
\text { g. Keunggulan teknologi } \\
\text { dan analisis data }\end{array}$ & $\begin{array}{l}\text { 3. SUMBER DAYA } \\
\text { UTAMA } \\
\text { a. Efek jaringan- } \\
\text { nya. efek } \\
\text { jaringan } \\
\text { antara peserta } \\
\text { (pengemudi), } \\
\text { Data, algoritma } \\
\text { b. Kemampuan } \\
\text { menganalisis } \\
\text { dan mendapat- } \\
\text { kan wawasan } \\
\text { c. Ketrampilan } \\
\text { rekayasa } \\
\text { d. Arsitektur } \\
\text { platform } \\
\text { e. Modal ventura } \\
\text { untuk menjaga } \\
\text { pertumbuhan } \\
\text { bisnis, } \\
\text { f. Nama merek } \\
\text { dan aset } \\
\text { g. Pengendara } \\
\text { dan aplikasi } \\
\text { pengemudi } \\
\text { h. dan produk } \\
\text { lainnya }\end{array}$ \\
\hline
\end{tabular}




\begin{tabular}{|c|c|c|}
\hline $\begin{array}{l}\text { 4. PROPOSISI NILAI } \\
\text { a. Bagi penumpang } \\
\text { nilainya adalah } \\
\text { bahwa ini meru- } \\
\text { pakan cara terbaik } \\
\text { untuk melakukan } \\
\text { perjalanan dan } \\
\text { melacak kedatan- } \\
\text { gan pengemudi. } \\
\text { b. Bagi pengemudi, } \\
\text { ini merupakan } \\
\text { peluang untuk } \\
\text { menghasilkan, } \\
\text { kebebasan me- } \\
\text { milih jam kerja } \\
\text { dan kemudahan } \\
\text { memulai. } \\
\text { c. Semua proposisi } \\
\text { masuk ke dalam } \\
\text { apa yang disebut } \\
\text { oleh para ekonomi } \\
\text { sebagai penguran- } \\
\text { gan biaya pencar- } \\
\text { ian dan biaya } \\
\text { transaksi yang } \\
\text { merupakan fitur } \\
\text { utama platform } \\
\text { dua sisi. }\end{array}$ & $\begin{array}{l}\text { 5. SEGMENTASI PELANG- } \\
\text { GAN } \\
\text { a. Demografis, yaitu usia, } \\
\text { status sosial ekonomi, } \\
\text { status keluarga, ke- } \\
\text { bangsaan; Geografis, } \\
\text { yaitu menurut kota, } \\
\text { pinggiran kota; } \\
\text { b. Geo-demografis; } \\
\text { Perilaku, yaitu ber- } \\
\text { dasarkan jam dan pola } \\
\text { kerja yang disukai. } \\
\text { c. Segmentasi: Mikro- } \\
\text { Geografi, yaitu rumah, } \\
\text { kantor, lokasi tipikal; } \\
\text { d. Pola penggunanaan, } \\
\text { apakah teratur, jarang; } \\
\text { e. Perilaku, seperti ke- } \\
\text { biasaan belanja }\end{array}$ & $\begin{array}{l}\text { 6. HUBUNGAN } \\
\text { KONSUMEN } \\
\text { a. Pertama } \\
\text { adalah hubun- } \\
\text { gan dengan } \\
\text { penumpang. } \\
\text { b. Kedua dengan } \\
\text { pengemudi. } \\
\text { c. Ketiga dengan } \\
\text { Publik yang } \\
\text { lebih luas. } \\
\text { d. Keempat den- } \\
\text { gan Regulator. }\end{array}$ \\
\hline $\begin{array}{l}\text { 7. SALURAN } \\
\text { a. Saluran untuk ke- } \\
\text { sadaran awal dan } \\
\text { akuisisi pelanggan } \\
\text { dapat berupa: } \\
\text { kampanye, } \\
\text { misal memberikan } \\
\text { voucher gratis ke } \\
\text { kota-kota baru; } \\
\text { b. Adanya liputan } \\
\text { media gratis ber- } \\
\text { dasarkan faktor } \\
\text { kebaruan; pro- } \\
\text { mosi dari mulut ke } \\
\text { mulut; } \\
\text { c. Kampanye di } \\
\text { media sosial dan } \\
\text { iklan digital; } \\
\text { d. Mengoptimalkan } \\
\text { semua channel } \\
\text { yang terdapat } \\
\text { pada platform } \\
\text { yang terhubung } \\
\text { dengan situs-situs } \\
\text { yang memiliki } \\
\text { peringkat tinggi. }\end{array}$ & $\begin{array}{l}\text { 8. STRUKTUR BIAYA } \\
\text { 1. Biaya perolehan } \\
\text { pelanggan. } \\
\text { 2. Biaya modal rata-rata, } \\
\text { 3. Biaya untuk pengem- } \\
\text { bangan fitur baru, } \\
\text { 4. Biaya untuk kasus } \\
\text { hukum } \\
\text { 5. Biaya penyeesaian, } \\
\text { kepatuhan terhadap } \\
\text { peraturan, } \\
\text { 6. Biaya transaksi, } \\
\text { 7. Biaya gaji, } \\
\text { 8. Biaya perluasan ke ban- } \\
\text { yak kota dan negara, } \\
\text { 9. Biaya infrastruktur, } \\
\text { bandwidt } \\
\text { 10. Biaya penelitian dan } \\
\text { pengembangan. }\end{array}$ & $\begin{array}{l}\text { 9. MODEL } \\
\text { PENDAPATAN } \\
\text { 1. Pemasukkan } \\
\text { iklan. Semakin } \\
\text { banyak jumlah } \\
\text { aplikasi yang } \\
\text { digunakan, } \\
\text { akan sema- } \\
\text { kin besar } \\
\text { pendapatan } \\
\text { yang diterima } \\
\text { melalui iklan. } \\
\text { 2. Revenue } \\
\text { sharing dengan } \\
\text { pihak perusa- } \\
\text { haan teleko- } \\
\text { munikasi. } \\
\text { 3. Pendapatan } \\
\text { dari database. }\end{array}$ \\
\hline
\end{tabular}

\section{Transportasi Ojek Online}

Transportasi ojek online merupakan transportasi yang berbasis suatu aplikasi tertentu, dimana konsumen memesan suatu sarana transportasi melalui sistem aplikasi di dalam smartphone. Saat konsumen melakukan pemesanan dengan menggunakan aplikasi, detail pemesanan seperti jarak tempuh, harga, identitas pengemudi, lama waktu pengemudi tiba ke lokasi konsumen, serta data perusahaan pengelolanya sudah langsung tersaji pada layar smartphone konsumen. Seluruh identitas pengemudi sudah diketahui secara pasti karena perusahaan pengelola telah melakukan proses verifikasi terlebih dahulu sebelum melakukan kerja sama kemitraan dengan pengemudi. Dengan adanya transportasi online, para penumpang kini tak perlu lagi menghampiri pangkalan ojek ataupun tak perlu lagi menunggu di pinggir jalan untuk mendapatkan taksi. Selain itu, para penumpang juga tidak harus terlibat dalam proses tawar-menawar karena tarif yang sudah ditentukan berdasarkan jarak tempuh. Ketika terjebak kemacetan di jalan, penumpang tidak perlu khawatir mengenai tarif yang membengkak seperti pada saat menaiki transportasi berargometer, karena tarif yang sudah ditentukan di awal perjalanan dengan berdasarkan jarak tempuh.

\section{Teori Kepuasan Pelanggan}

Menurut Rangkuti (2013), kepuasan pelanggan adalah evaluasi paska pembelian, dimana alternatif yang dibeli minimal sama atau melebihi harapan pelanggan. Berdasarkan pengertian ini, kepuasan pelanggan adalah tingkat perasaan seseorang setelah membandingkan kinerja atau hasil yang dirasakan dibandingkan dengan harapannya.

Beberapa pengertian dari kepuasan pelanggan menurut beberapa ahli, yang dikutip dari Rangkuti (2013) adalah sebagai berikut :

1. Respons atau tanggapan konsumen mengenai pemenuhan kebutuhan. Kepuasan merupakan penilaian mengenai ciri keistimewaan produkatau jasa, atau produk itu sendiri, yang menyediakan tingkat kesenangan konsumen berkaitan dengan pemenuhan kebutuhan konsumsi konsumen (Zeithhaml dan Bitner (2000:75).

2. Kepuasan konsumen adalah sejauh mana anggapan kinerja produk/jasa memenuhi harapan pembeli. Bila kinerja produk/jasa lebih tinggi dari harapan pelanggan, maka pembelinya merasa puas atau amat gembira (Kotler dan Amstrong (2001: 9)

3. Keadaan emosional, reaksi paska pembelian dapat berupa kemarahan, ketidakpuasan. Kejengkelan, kegembiraan, atau kesenangan (lovelock). Perasaan pelanggan terhadap satu jenis pelayanan yang didapatkan (Pasuraman).

4. Kepuasan pelanggan merupakan perasaan 
seseorang terhadap kinerja suatu produk atau jasa yang dibandingkan dengan harapannya (Schiffman)

5. Kepuasan adalah konsep yang jauh lebih luas dari hanya sekedar penilaian kualitas pelayanan, tetapi juga dipengaruhi oleh faktor-faktor lain (Ziethaml).

Dapat disimpulkan melalui berbagai pengertian di atas bahwa kepuasan pelanggan dipengaruhi oleh berbagai faktor, yaitu: Service quality, Product quality, Price, Situational factor, dan Personal factor.

Service Quality merupakan kualitas jasa pelayanan yang diberikan kepada pelanggan. Tidak ada gunanya produk berkualitas kalau tidak diimbangi dengan kualitas pelayanan yang luar biasa. Pelanggan akan merasa kecewa karena tidak dilayani dengan baik. Sebaliknya, pelayanan yang luar biasa juga tidak akan ada artinya apabila tidak didukung oleh produk yang berkualitas serta harga yang sesuai dengan harapan pelanggan.

Selain itu strategi peningkatan kepuasan pelanggan juga sangat dipengaruhi oleh faktorfaktor internal yang ada di dalam diri pelanggan itu sendiri, seperti faktor situasional dan personal. Seringkali kita hanya berjalan-jalan untuk melihat-lihat pusat perbelanjaan, namum apabila pengaruh situasional, misalnya ada kegiatan promosi, diskon, menjelang lebaran, tahun baru, serta berbagai kegiatan dapat meningkatkan impulse buying, maka faktor situasional dapat mempengaruhi proses pengambilan keputusan di dalam melakukan pembelian yang tidak kita rencanakan sebelumnya.

Begitu juga faktor personal, orang yang memiliki karakter suka berbelanja, banyak mempengaruhi gaya hidup dan proses pengambilan keputusan untuk pembelian.

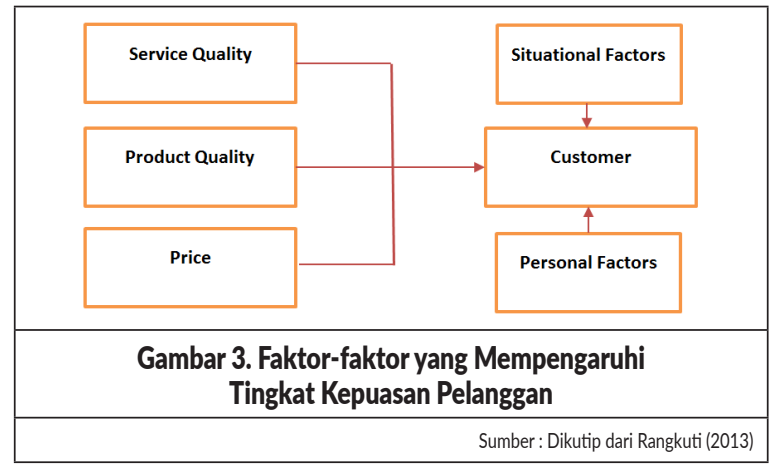

Di dalam penelitian ini di indentifikasi dan diduga faktor-faktor yang mempengaruhi tingkat kepuasan pelanggan (Y) adalah: keamanan dan kenyamanan (X1); pelayanan (X2); ketepatan waktu (X3); kemudahan pemesanan (X4); dan kesesuaian harga (X5)

\section{Perumusan Masalah}

Berdasarkan uraian latar belakang dan permasalahan di atas, maka pertanyaan penelitian yang ingin dijawab di dalam penelitian ini adalah sebagai berikut :

a. Faktor-faktor apa saja yang mempengaruhi tingkat kepuasan pelanggan terhadap model bisnis platform Ojek Online?

b. Bagaimana faktor-faktor tersebut mempengaruhi tingkat kepuasan pelanggan terhadap model bisnis platform Ojek Online?

\section{Batasan Masalah}

Di dalam penelitian ini diberikan pembatasan pokok masalah, yaitu sebagai berikut :

a. Penelitian transportasi online adalah alat transportasi online roda dua, atau dikenal dengan nama Ojek Online.

b. Responden yang dipilih untuk melihat tingkat kepuasan adalah konsumen pengguna yang biasa menggunakan Ojek Online sebagai alat transportasi.

c. Pemilihan responden dibatasi untuk kota Jakarta dan Bogor saja.

\section{Tujuan Penelitian}

Adapun tujuan penelitian adalah sebagai berikut :

a. Untuk mengetahui faktor-faktor apa saja yang mempengaruhi tingkat kepuasan pelanggan terhadap model bisnis platform Ojek Online.

b. Untuk mengetahui bagaimana pengaruh faktor-faktor tersebut terhadap tingkat kepuasan pengguna model bisnis platform Ojek Online.

\section{METODE}

\section{Waktu dan Tempat}

Penelitian ini telah dilaksanakan pada 
20 sampai 27 November 2018 di Bogor. Penentuan lokasi dilakukan secara sengaja (purposive) dengan pertimbangan bahwa lokasi Bogor dapat mewakili responden pengguna jasa ojek online.

\section{Metode Penelitian}

Metode yang digunakan dalam penelitian ini adalah metode penelitian kuantitatif, penelitian yang menghasilkan penemuanpenemuan yang dapat dicapai (diperoleh) dengan menggunakan prosedur-prosedur statistik atau cara-cara lain dari kuantifikasi atau pengukuran (Sujarweni, 2014:39). Dalam penelitian ini menggunakan model penelitian deskriptif yaitu penelitian yang dilakukan untuk mengetahui dan menjadi mampu untuk menjelaskan karakteristik variabel yang diteliti dalam suatu situasi (Sekaran, 2014:158).

\section{Penentuan Responden}

Penentuan responden dilakukan secara purposive sampling, dimana peneliti mengambil responden adalah orang-orang yang terpilih menurut kriteria spesifik sesuai dengan tujuan penelitian. Kriteria spesifik penelitian adalah responden yang dianggap menggunakan jasa alat transportasi ojek online.

\section{Pengumpulan Data}

Data yang dikumpulkan dalam penelitian ini adalah data primer dan data sekunder. Data primer adalah data yang langsung diambil dari responden melalui kuesioner. Data primer tersebut meliputi : jenis kelamin, usia, pekerjaan, pendapatan, penggunaan dan jenis layanan gojek yang digunakan, cara pembayaran, keamanan dan kenyaman, pelayanan, waktu dan kemudahan pemesanan gojek, kemudahaan pembayaran dan harga, serta tingkat kepuasan penggunaan gojek.

Data sekunder diperoleh dari buku, majalah, majalah berupa laporan keuangan publikasi perusahaan, laporan pemerintah, artikel, buku-buku sebagai teori, dan lain sebagainya.

\section{Definisi Operasional dan Pengukuran}

\section{Variabel}

Pada penelitian ini menggunakan 5 variabel yang terdiri dari 1 variabel tidak bebas (Y) dan 5 variabel bebas (X1, X2, X3, $\mathrm{X} 4, \mathrm{X} 5)$, dengan penjelasan sebagai berikut:

$\mathrm{Y}=$ Tingkat Kepuasan Pelanggan

$\mathrm{X} 1$ = Keamanan dan Kenyamanan

$\mathrm{X} 2$ = Tingkat Pelayanan

$\mathrm{X} 3$ = Ketepatan Waktu

$\mathrm{X} 4$ = Kemudahan Pemesanan

X5 = Kesesuaian Harga

Tabel 2. Definisi Operasional dan Pengukuran Variabel

\begin{tabular}{|c|c|c|}
\hline $\begin{array}{l}\text { VARIABEL DAN DEFINISI } \\
\text { OPERASIONAL }\end{array}$ & DIMENSI DATA & SKALA \\
\hline $\begin{array}{l}\text { Y - Tingkat Kepuasan } \\
\text { Pengguna Gojek Online }\end{array}$ & $\begin{array}{l}\text { 1. Saya sangat senang menggunakan } \\
\text { layanan ojek online. } \\
\text { 2. Pelayanan yang dirasakan lebih baik } \\
\text { dari ekspektasi saya. } \\
\text { 3. Secara keseluruhan, saya sangat puas } \\
\text { dengan pelayanan ini. }\end{array}$ & Likert \\
\hline $\begin{array}{l}\text { X1 - Keamanan dan } \\
\text { Kenyamanan }\end{array}$ & $\begin{array}{l}\text { 1. Anda merasakan keamanan dan } \\
\text { kenyamanan dalam menggunakan } \\
\text { layanan ojek online. } \\
\text { 2. Apakah driver menaati peraturan lalu } \\
\text { lintas. } \\
\text { 3. Driver menggunakan seragam dan } \\
\text { berpenampilan rapih. }\end{array}$ & Likert \\
\hline X2 - Pelayanan & $\begin{array}{l}\text { 1. Driver bersikap responsif. } \\
\text { 2. Driver bersikap sopan. } \\
\text { 3. Anda dapat memberikan umpan balik. }\end{array}$ & Likert \\
\hline X3 - Ketepatan Waktu & $\begin{array}{l}\text { 1. Waktu tunggu untuk pemesanan } \\
\text { singkat (kurang dari } 10 \text { menit). } \\
\text { 2. Driver mengantar Anda dalam waktu } \\
\text { singkat. } \\
\text { 3. Driver mengantar Anda ke tujuan } \\
\text { dengan rute tepat. }\end{array}$ & Likert \\
\hline $\begin{array}{l}\text { X4 - Kemudahan } \\
\text { Pemesanan }\end{array}$ & $\begin{array}{l}\text { 1. Anda dapat mengetahui posisi driver } \\
\text { (order tracking). } \\
\text { 2. Ada personalisasi aplikasi yang } \\
\text { memudahkan pelanggan (misalnya } \\
\text { history pemesanan). }\end{array}$ & Likert \\
\hline X5 - Kesesuaian Harga & $\begin{array}{l}\text { 1. Pembayaran dilakukan dengan } \\
\text { mudah. } \\
\text { 2. Harga ojek online murah. } \\
\text { 3. Harga ojek sesuai dengan jarak. }\end{array}$ & Likert \\
\hline
\end{tabular}

\section{Rentang Skala Likert}

Pengukuran masing-masing variabel dalam penelitian ini menggunakan skala Likert. Skala Likert digunakan untuk mengukur sikap, pendapat, dan persepsi seorang atau sekelompok orang mengenai suatu fenomena sosial. Dengan penggunaan skala Likert maka variabel-variabel yang akan diukur dijabarkan menjadi indikator variabel. Kemudian indikator tersebut dijadikan titik tolak untuk menyusun item-item instrumen yang dapat berupa pertanyaan (Sugiyono, 2010:132). Pada penggunaan skala Likert menggunakan lima alternatif 
tingkatan jawaban, dimana masing-masing jawaban memiliki bobot nilai yang nantinya digunakan untuk pengukuran.

\begin{tabular}{|c|c|c|}
\hline \multicolumn{3}{|c|}{ Tabel 3. Tingkatan Jawaban Skala Likert } \\
\hline KODE & JAWABAN & BOBOT \\
\hline SS & Sangat Setuju & 5 \\
\hline S & Setuju & 4 \\
\hline N/R & Netral / Ragu-ragu & 3 \\
\hline TS & Tidak Setuju & 2 \\
\hline STS & Sangat Tidak Setuju & 1 \\
\hline \multicolumn{2}{|c|}{ Sumber: Sugiyono (2010:133) } \\
\hline
\end{tabular}

\section{Statistik Deskriptif}

Statistik deskriptif dengan menggunakan survei dilakukan dengan membagikan kuesioner secara online kepada responden yaitu pelanggan yang menggunakan transportasi Ojek Online. Data survei kemudian dikelompokkan berdasarkan karakteristik responden, pekerjaan, pendapatan per bulan, frekwensi menggunakan Ojek Online, jenis pembayaran yang sering digunakan, pemberian tips, dan alasan utama memilih transportasi Ojek Online. Selanjutnya data survei tersebut akan diolah dan diinterpretasikan hasilnya.

\section{Uji Validitas}

Sebuah instrumen yang akan digunakan dalam penelitian harus dapat diketahui valid atau tidaknya instrumen tersebut. Valid berarti instrument tersebut dapat digunakan untuk mengukur apa yang seharusnya diukur (Sugiyono, 2010:455). Untuk menguji validitas dari suatu instrumen/alat ukur, maka terlebih dahulu harus dilakukan penghitungan koefisien korelasi dengan menggunakan rumus Product Moment sebagai berikut:

$$
r_{x y}=\frac{n \sum x_{i} y_{i}-\left(\sum x_{i}\right)\left(\sum y_{i}\right)}{\sqrt{\left(n \sum x_{i}^{2}-\left(\sum x_{i}\right)^{2}\right)}\left(n \sum y_{i}^{2}-\left(\sum y_{i}\right)^{2}\right)}
$$

Keterangan:

rxy $=$ koefisien korelasi

$\Sigma x i=$ jumlah skor item

$\Sigma y i=$ jumlah skor total

¿xiyi $=$ total perkalian skor item

$\mathrm{n} \quad=$ jumlah responden $\sum \mathrm{xi}^{2}=$ jumlah kuadrat skor item

$\sum \mathrm{yi}^{2}=$ jumlah kuadrat skor total

Sebuah instrumen penelitian dapat dikatakan valid jika nilai koefisien korelasi (rxy) lebih besar dari nilai $\mathrm{r}$ yang terdapat dalam tabel $r$ product moment.

\section{Uji Realibilitas}

Menurut Imam Ghazali (2011: 47) reliabilitas adalah alat untuk mengukur suatu kuesioner yang merupakan indikator dari variabel atau kontruk. Suatu kuesioner dikatakan reliabel atau handal jika jawaban seseorang terhadap pernyataan adalah sejalan atau stabil dari waktu ke waktu. Uji reliabilitas pada penelitian ini menggunakan rumus Cronbach's Alpha sebagai berikut:

$$
r_{11}=\left[\frac{K}{(K-1)}\right]\left[1-\frac{\sum \sigma_{b}^{2}}{\sigma_{t}^{2}}\right]
$$

\section{Keterangan:}

r11 = reliabilitas instrumen

$\Sigma \sigma b^{2}=$ jumlah varians butir

$\mathrm{K}$ = banyaknya butir indikator

$\sigma \mathrm{t}^{2}=$ varians total

Salah satu cara atau metode untuk menentukan reabilitas instrumen yaitu dengan metode uji statistik Alpha ( $\alpha$ ). Yaitu metode yang ditemukan oleh tuan Cronbach, maka disebutan juga sebagai uji Cronbach Alpha. Dimana suatu variable dikatakan reliabel jika memberikan nilai Cronbach Alpha $(\alpha)>0,60$ (Umar, 2008:174).

\section{Uji Normalitas}

Uji normalitas adalah sebuah uji yang dilakukan dengan tujuan untuk menilai sebaran sebuah kelompok data atau variabel apakah memiliki sebaran normal. Sudarmanto (2005), menyebutkan bahwa uji normalitas bertujuan untuk menguji apakah dalam model regresi variabel penggangu/residual memiliki distribusi normal. Sementara Ghozali (2006), mengatakan bahwa pengujian normalitas dapat dilakukan dengan mengamati grafik normal Probability Plot (P-Plot) hasil pengolahan dengan SPSS. Jika variabel berdistribusi normal, maka 
penyebaran plot akan berada disekitar dan disepanjang garis 45 derajat. Model regresi yang baik adalah yang memiliki distribusi normal atau mendekati normal. Distribusi normal akan membentuk garis lurus diagonal. Jika distribusi datanya normal, maka garis yang menggambarkan data yang sesungguhnya akan mengikuti garis diagonalnya.

\section{Uji Heteroskedastisitas}

Heteroskedastisitas adalah pengujian dimana error dari setiap variabel bebas semuanya mempunyai variasi yang tidak sama, atau adanya perbedaan variance residual. Tujuan dari pengujian ini adalah untuk melihat apakah di dalam sebuah model regresi ada hubungan antara variabel pengganggu dengan variabel bebasnya, atau digunakan untuk menguji terjadinya perbedaan variance residual suatu periode pengamatan ke periode pengamatan yang lain, yang merupakan hubungan antara nilai yang diprediksi dengan Studentized Delete Residual nilai tersebut (Nugroho, 2005).

Untuk mendeteksi ada tidaknya gejala heteroskedastisitas dapat dilakukan dengan cara Uji Park, Uji Glejser, Uji BreunschPagan, Uji Goldfield-Quandt, White Test (Juanda, 2009: 130). Pendeteksian dapat pula dengan menggunakan metode grafik, dengan melakukan pengamatan menggunakan grafik plot antara nilai prediksi variabel terikat (ZPRED) dengan residualnya (SRESEID). Apabila tidak ada pola yang jelas serta titiktitik menyebar di atas dan di bawah angka 0 (nol) pada sumbu Y, maka dapat disimpulkan tidak terjadi heteroskedastisitas dalam data.

\section{Uji Multikolinearitas}

Uji multikolinieritas bertujuan untuk mengetahui apakah adanya korelasi yang tinggi antar variabel yang dikenal dengan multikolinieritas. Untuk mengetahui apakah antar variabel terjadi multikolinieritas dapat digunakan nilai Tolerance dan VIF (Variance Inflation Factor) dengan rumus sebagai berikut.

> Tolerance $<0,10$ mengindikasikan tidak ada korelasi yang signifikan antar variabel prediktor, Tolerance $>0,10$ mengindikasikan bahwa ada korelasi antar variabel prediktor, maka terjadi multikolinieritas.

> VIF $<10$ mengindikasikan tidak ada korelasi yang signifikan antar variabel prediktor, jika VIF > 10 mengindikasikan bahwa ada korelasi antar variabel prediktor, maka terjadi multikolinieritas.

\section{Analisis Regresi Linier Berganda}

Analisis regresi linier berganda adalah untuk mengetahui pengaruh antara dua atau lebih variabel bebas dengan satu variabel tidak bebas yang ditampilkan dalam bentuk persamaan regresi (Priyatno, 2016:92). Analisis regresi linier berganda adalah analisis regresi dengan menggunakan dua atau lebih variabel bebas yang diteliti pengaruhnya terhadap variabel tidak bebas. Selanjutnya, berikut adalah bentuk persamaan regresi linier berganda yang digunakan ada penelitian ini:

$\mathrm{Y}=\mathrm{a}+\mathrm{b}_{1} \mathrm{X}_{1}+\mathrm{b}_{2} \mathrm{X}_{2}+\mathrm{b}_{3} \mathrm{X}_{3}+\mathrm{b}_{4} \mathrm{X}_{4}+\mathrm{b}_{5} \mathrm{X}_{5}$

Keterangan:

$\mathrm{Y}=$ Tingkat kepuasan pelanggan

$\mathrm{X}_{1}=$ Keamanan dan Kenyamanan

$\mathrm{X}_{2}=$ Pelayanan

$\mathrm{X}_{3}=$ Ketepatan Waktu

$\mathrm{X}_{4}=$ Kemudahan Pemesanan

$\mathrm{X}_{5}=$ Kesesuaian Harga

\section{Koefisien Determinasi}

Untuk mengetahui seberapa besar variabel independen bisa menjelaskan variabel dependen secara bersama-sama atau simultan, maka perlu diketahui nilai koefisien determinasi, dalam hal ini digunakan nilai $\mathrm{R}_{2}$ ( $\mathrm{R}$ square) karena nilai variabel bebas yang diukur terdiri dari nilai rasio absolut dan nilai perbandingan.

> Nilai $\mathrm{R}_{2}$ terletak antara 0 dan 1 .

> Makin besar nilai $\mathrm{R}_{2}$ berarti semakin tidak tepat garis regresi tersebut mewakili data dari hasil observasi.

> Jika nilai $\mathrm{R}_{2}=1$, pendekatan tersebut terdapat kecocokan sempurna. 
> Jika nilai $\mathrm{R}_{2}=0$, tidak ada kecocokan pendekatan.

Dimana koefisien determinasi merupakan nilai yang menggambarkan seberapa besar perubahan dari variabel terikat bisa dijelaskan oleh perubahan dari variabel bebasnya. Rumus dari koefisien deterrminasi adalah sebagai berikut:

$\mathrm{KD}=\mathrm{r}_{2} \mathrm{X} 100 \%$

Dimana:

> $\mathrm{KD}=$ Koefisien Determinasi

$>\mathrm{R}_{2}=\mathrm{R}$ Square

Koefisien ini juga digunakan untuk mengukur besarnya sumbangan dari variabel bebas terhadap naik turunnya nilai variabel terikat.

15. Uji t (Parsial)

Uji $t$ atau dapat disebut pengujian hipotesis parsial biasanya digunakan untuk mengetahui apakah dalam model regresi, variabel bebas secara parsial berpengaruh signifikan terhadap terhadap variabel terikat (Priyatno, 2008:83).

Pengujian hipotesis Uji t dalam penelitian ini digunakan untuk menguji pengaruh dari setiap variabel bebas, yaitu keamanan dan kenyamanan $\left(\mathrm{X}_{1}\right)$, pelayanan $\left(\mathrm{X}_{2}\right)$, ketepatan waktu $\left(\mathrm{X}_{3}\right)$, kemudahan pemesanan $\left(\mathrm{X}_{4}\right)$, kesesuaian harga $\left(\mathrm{X}_{5}\right)$ berpengaruh secara parsial terhadap variabel tidak bebas, yaitu tingkat kepuasan pelanggan (Y). Hipotesis untuk pengujian t, dengan $\alpha=5 \%$. Kriteria pengujian berdasarkan probabilitas dapat dijelaskan sebagai berikut.

> Jika t hitung $>\mathrm{t}$ tabel, atau $\mathrm{t}$ signifikan $<$ 0,05, maka H0 ditolak dan menerima H1

> Jika t hitung $<\mathrm{t}$ tabel, atau $\mathrm{t}$ signifikan $>$ 0,05, maka H0 diterima dan menolak H1

16. Uji-F (Simultan)

Uji $F$ digunakan untuk mengetahui apakah dalam model regresi, variabel bebas secara simultan berpengaruh signifikan terhadap terhadap variabel tidak bebas (Priyatno, 2008:81). Pengujian hipotesis Uji F dalam penelitian ini secara simultan dimaksudkan untuk mengukur besarnya pengaruh variabel bebas yaitu, keamanan dan kenyamanan $\left(\mathrm{X}_{1}\right)$, pelayanan $\left(\mathrm{X}_{2}\right)$, ketepatan waktu $\left(\mathrm{X}_{3}\right)$, kemudahan pemesanan $\left(\mathrm{X}_{4}\right)$, kesesuaian harga $\left(\mathrm{X}_{5}\right)$ secara simultan terhadap variabel tidak bebas yaitu kepuasan pelanggan (Y). Z). Hipotesisnya adalah sebagai berikut:

> Jika $\mathrm{F}_{\text {hitung }}>\mathrm{F}_{\text {tabel }}$ atau $\mathrm{F}_{\text {hitung }}$ signifikan $<0,005$, maka $\mathrm{H}_{0}$ ditolak dan menrima $\mathrm{H}_{1}$, ada pengaruh yang signifikan secara simultan antara variabel bebas terhadap variabel tidak bebas.

> Jika $\mathrm{F}_{\text {hitung }}<\mathrm{F}_{\text {tabel }}$ atau $\mathrm{F}_{\text {hitung }}$ signifikan $>$ 0,05, maka $\mathrm{H}_{0}$ diterima, dan menerima $\mathrm{H}_{1}$, tidak ada pengaruh yang signifikan secara simultan antara variabel bebas terhadap variabel tidak bebas.

\section{HASIL dan PEMBAHASAN}

\section{Karakteristik Responden}

Jumah responden yang diteliti sebanyak 118 responden, dengan karakteristik responden yang dianalisis di dalam penelitian ini meliputi jenis kelamin, umur, pekerjaan, pendapatan per bulan, pelayanan ojek online dalam seminggu, jenis layanan ojek yang digunakan, jenis pembayaran yang sering digunakan, pemberian tips, dan alasan utama memilih ojek Online.

\section{Jenis Kelamin}

Hasil frekwensi jawaban responden ojek online berdasarkan jenis kelamin ditunjukkan pada gambar berikut :

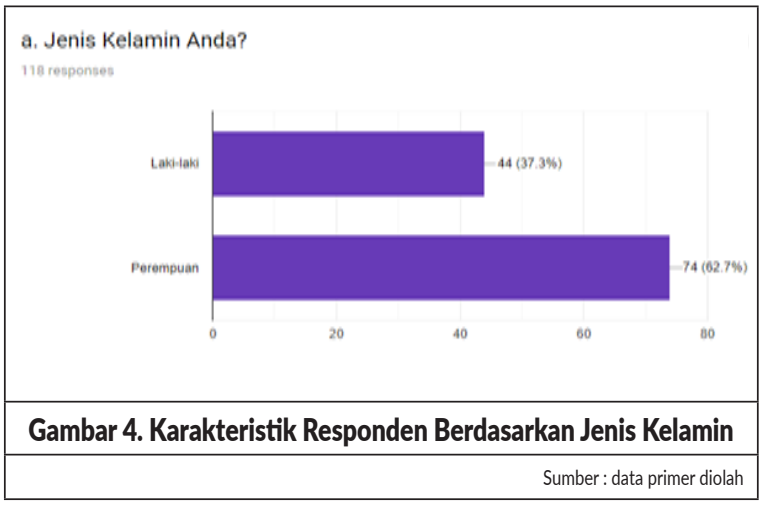

Berdasarkan gambar di atas, data responden yang diteliti paling banyak adalah perempuan sebesar 62,7 persen, sementara data responden laki-laki sebanyak 37,3 persen. 
Usia

Deskripsi karakteristik responden berdasarkan umur dapat dilihat pada gambar di bawah.

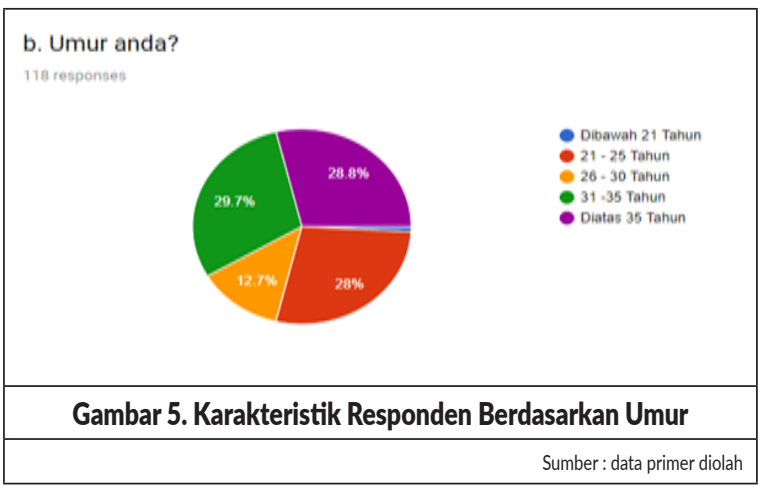

Berdasarkan jawaban responden yang menjawab kuesioner, responden dengan range umur 31-35 memberikan jawaban yang paling banyak terhadap pertanyaan kuesioner yang diberikan, kemudian diikuti dengan umur di atas 35 tahun masing-masing sebesar 29,7 persen dan 28, 8 persen. Sementara responden dengan umur di bawah 21 tahun adalah responden yang paling sedikit memberikan jawaban kuesioner, yaitu hanya sebesar 0,8 persen saja.

\section{Pekerjaan}

Deskripsi karakteristik responden berdasarkan pekerjaan dapat dilihat pada gambar di bawah berikut.

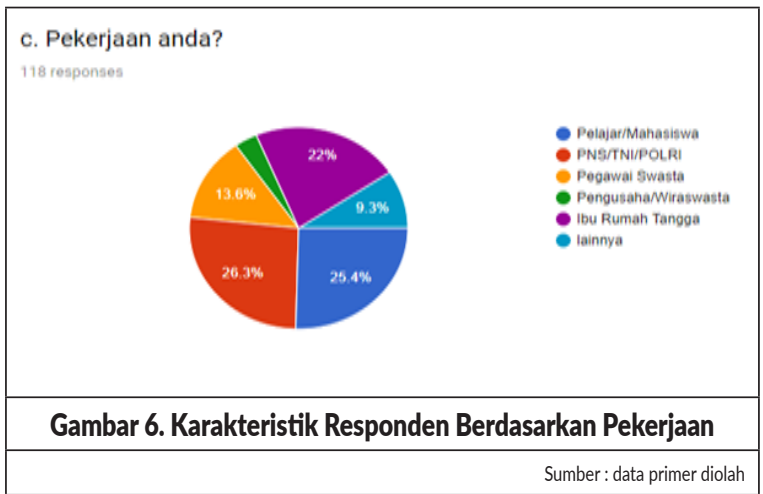

Dari gambar di atas terdapat 26,3 persen responden yang bekerja sebagai PNS/TNI/POLRI, 25,4 persen adalah Pelajar/Mahasiswa, sebanyak 22 persen adalah ibu rumah tangga, 13,6 persen Pegawai Swasta, Lainnya sebanyak 9,3 persen, dan responden sisanya adalah Pengusaha/Wiraswasta sebesar 3,4 persen.

\section{Pendapatan per Bulan}

Deskripsi karakteristik responden berdasarkan Pendapatan per Bulan dapat dilihat pada gambar berikut di bawah.

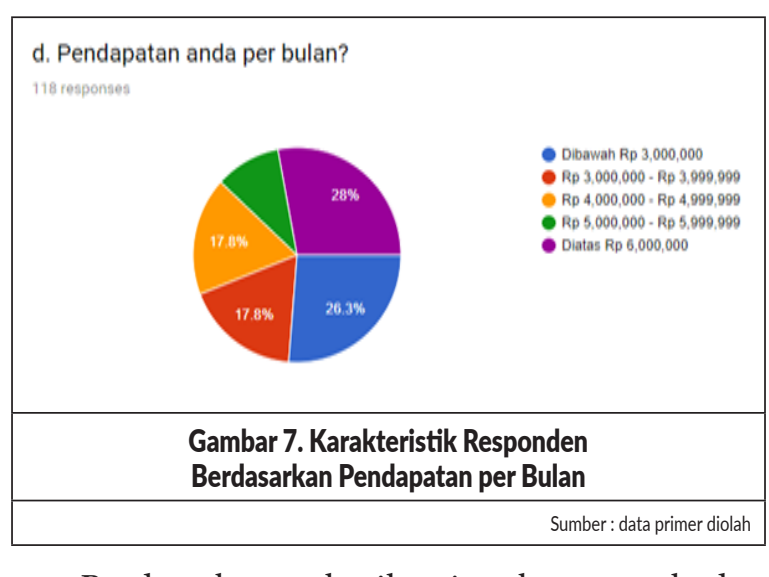

Berdasarkan hasil jawaban terhadap kuesioner yang diberikan dari gambar di atas, responden dengan karakteristik pendapatan per bulan diatas Rp6.000.000,- memberikan jawaban yang paling banyak, yaitu sebesar 28 persen, kemudian diikuti dengan responden dengan karakteristik pendapatan per bulan di bawah 3 juta sebanyak 26,3 persen. Sisanya adalah responden dengan karakteristik pendapatan per bulan antara Rp3.000.000,- sampai dengan Rp6.000.000,-

\section{Frekwensi Penggunaan Gojek Online}

Deskripsi karakteristik responden berdasarkan frekwensi penggunaan gojek online dapat dilihat pada gambar berikut di bawah.

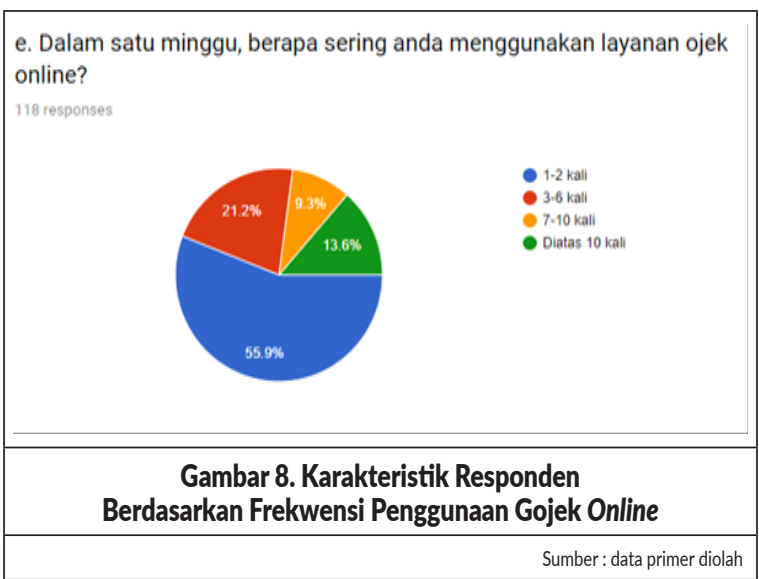

Dari jawaban responden, dapat dilihat dari gambar di atas, responden dengan karakteristik frekwensi penggunaan gojek online dalam seminggu paling besar adalah responden yang menggunakan gojek online dengan frekwensi 
sebanyak 1-2 kali, yaitu sebesar 55,9 persen. Sementara responden dengan karakteristik frekwensi penggunaan gojek online dalam seminggu paling kecil adalah responden yang menggunakan gojek online dengan frekwensi sebanyak 7-10 kali, yaitu sebesar 9,3 persen.

\section{Jenis Layanan Ojek Online yang digunakan}

Berdasarkan karakteristik jenis layanan ojek online yang digunakan dapat dilihat pada gambar berikut di bawah.

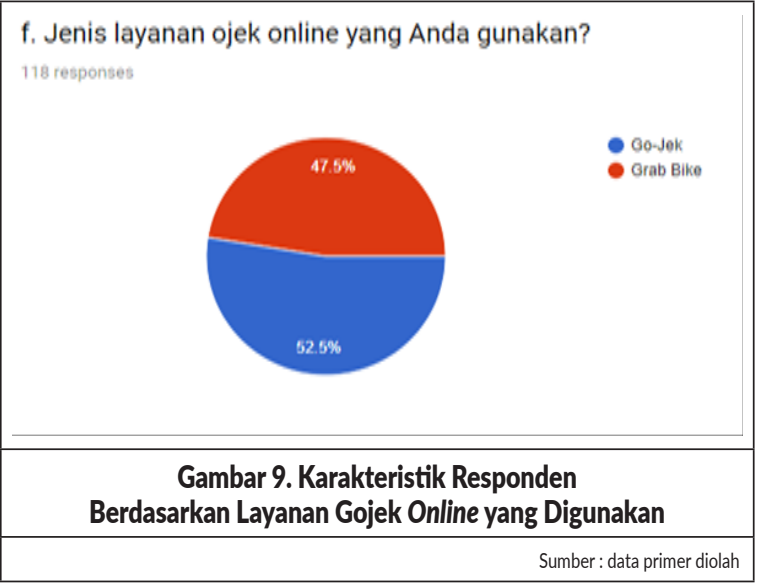

Berdasarkan jawaban responden pada gambar di atas, dapat diketahui bahwa jasa layanan ojek online yang digunakan paling besar menggunakan Gojek, yaitu sebesar 52,5 persen. Sementara jenis layanan ojek online yang menggunakan Grab Bike sebesar 47,5 persen.

\section{Jenis Pembayaran yang Digunakan}

Berdasarkan karakteristik jenis pembayaran yang digunakan dapat dilihat pada gambar berikut dibawah.

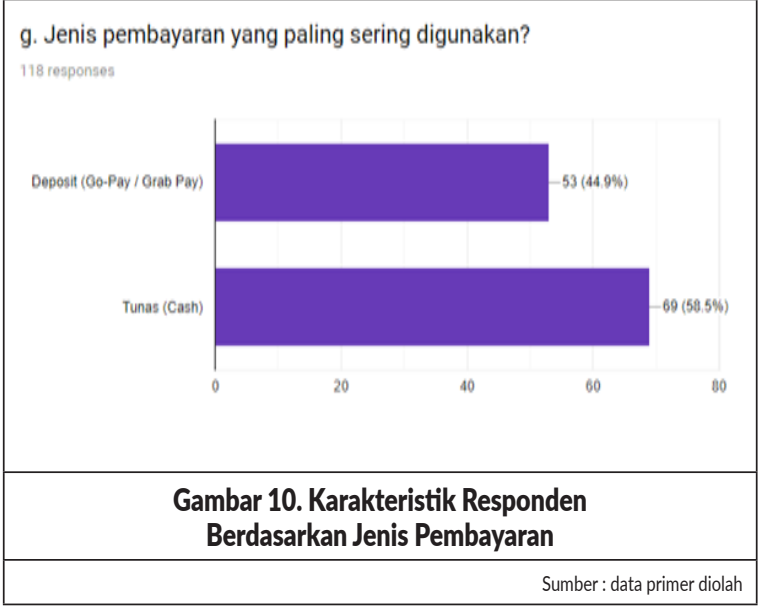

Dari data jawaban di atas, dapat diketahui bahwa jenis pembayaran yang paling sering digunakan adalah dengan menggunakan Tunai (Cash), yaitu sebanyak 69 responden (58,5 persen), sementara jenis pembayaran dengan menggunakan Deposit (Go-Pay/Grab pay) sebanyak 53 responden (44,9 persen).

\section{Tips}

Apakah responden memberikan tips setelah menggunakan jasa layanan transportasi ojek online dapat dilihat pada gambar berikut di bawah.

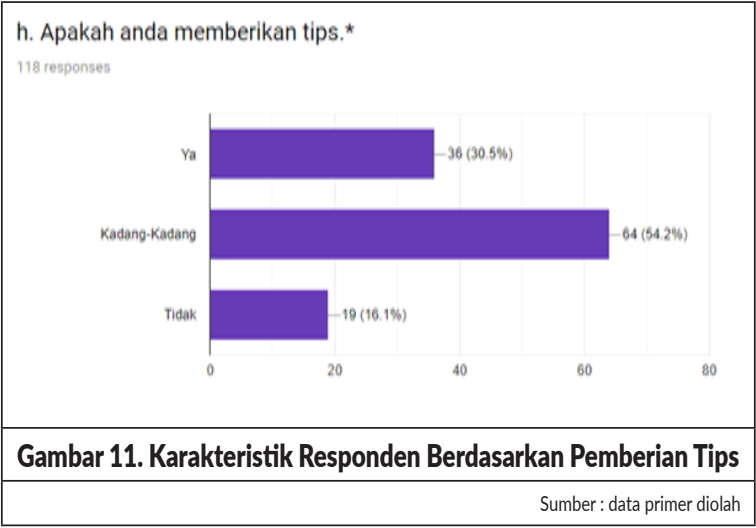

Berdasarkan jawaban di atas dapat disimpulkan bahwa sebagian besar responden memberikan tips setelah menggunakan jasa layanan transportasi ojek online.

\section{Analisis Data Penelitian Uji Validitas}

Untuk menguji apakah setiap pertanyaan pada pada masing variabel valid atau tidak, dilakukan Uji Validitas dengan SPSS 25, dengan kriteria, setiap kuesioner dinyatakan valid apabila nilai $\mathrm{r}_{\text {hitung }}>\mathrm{r}_{\text {tabel }}$ dengan taraf signifikan $\alpha=$ 0,05 (5\%), tingkat kepercayaan pengujian adalah $95 \%$. Sebaliknya apabila $\mathrm{r}_{\text {hitung }}<\mathrm{r}_{\text {tabel }}$ maka butir kuesioner pada setiap variabel dinyatakan tidak valid. Uji validitas juga dapat dilihat apabila Nilai signifikansi $<0,05$, maka setiap kuesioner dinyatakan valid.

Berdasarkan Uji Validitas dengan menggunakan SPSS 25, didapatkan hasil sebagai berikut: 


\begin{tabular}{|c|l|c|c|c|c|}
\hline \multicolumn{7}{c}{ Tabel 4. Hasil Uji Validitas Berdasarkan } \\
Variabel Keamanan dan Kenyamanan $\left(\mathbf{X}_{1}\right)$
\end{tabular}

Berdasarkan data tabel di atas, dapat dikatakan bahwa semua item pernyataan pada variabel $\mathrm{X}_{1}$, nilai $\mathrm{r}_{\text {hitung }}>0,159$, atau nilai signifikansi $<0,05$, yang berarti bahwa semua item pernyataan pada variabel $\mathrm{X}_{1}$ adalah valid.

\begin{tabular}{|c|l|c|c|c|c|}
\hline \multicolumn{6}{|c|}{ Tabel 5. Hasil Uji Validitas Berdasarkan Variabel Pelayanan $\left(\mathbf{X}_{2}\right)$} \\
\hline No & \multicolumn{1}{|c|}{ Item Kuisioner } & $\begin{array}{c}\text { Nilai } \\
\mathbf{R}_{\text {hting }}\end{array}$ & Nilai Sig & $\begin{array}{c}\text { Nilai } \\
\mathbf{R}_{\text {tobel }}\end{array}$ & Keputusan \\
\hline 1 & Driver bersikap responsif & 0,859 & 0,000 & 0,1509 & Valid \\
\hline 2 & Driver bersikap sopan & 0,901 & 0,000 & 0,1509 & Valid \\
\hline 3 & $\begin{array}{l}\text { Anda dapat memberikan } \\
\text { umpan balik (feedback) } \\
\text { dan komentar terkait } \\
\text { kinerja pelayanan }\end{array}$ & 0,818 & 0,000 & 0,1509 & Valid \\
\hline \multicolumn{7}{|c|}{} & \multicolumn{5}{|c|}{ Data SPSS diolah } \\
\hline
\end{tabular}

Berdasarkan data tabel di atas, dapat dikatakan bahwa semua item pernyataan pada variabel $\mathrm{X}_{2}$, nilai $\mathrm{r}_{\text {hitung }}>0,159$, atau nilai signifikansi $<$ 0,05 , yang berarti bahwa semua item pernyataan pada variabel $\mathrm{X}_{2}$ adalah valid.

\begin{tabular}{|c|l|c|c|c|c|}
\hline \multicolumn{6}{|c|}{ Tabel 6. Hasil Uji Validitas Berdasarkan Variabel Waktu $\left(\mathbf{X}_{3}\right)$} \\
\hline No & \multicolumn{1}{|c|}{ Item Kuisioner } & $\begin{array}{c}\text { Nilai } \\
\mathbf{R}_{\text {htung }}\end{array}$ & Nilai Sig & $\begin{array}{c}\text { Nilai } \\
\mathbf{R}_{\text {tobel }}\end{array}$ & Keputusan \\
\hline 1 & $\begin{array}{l}\text { Waktu tunggu untuk } \\
\text { pemesanan singkat } \\
\text { (kurang dari 10 menit) }\end{array}$ & 0,815 & 0,000 & 0,1509 & Valid \\
\hline 2 & $\begin{array}{l}\text { Driver mengantar Anda } \\
\text { dalam waktu singkat }\end{array}$ & 0,862 & 0,000 & 0,1509 & Valid \\
\hline 3 & $\begin{array}{l}\text { Driver mengantar Anda ke } \\
\text { tujuan dengan rute tepat }\end{array}$ & 0,842 & 0,000 & 0,1509 & Valid \\
\hline \multicolumn{7}{|c|}{} \\
\hline
\end{tabular}

Berdasarkan data tabel di atas, dapat dikatakan bahwa semua item pernyataan pada variabel $\mathrm{X}_{3}$, nilai $\mathrm{r}_{\text {hitung }}>0,159$, atau nilai signifikansi $<0,05$, yang berarti bahwa semua item pernyataan pada variabel $\mathrm{X}_{3}$ adalah valid.

\begin{tabular}{c|c|c|c|c|c|}
\hline \multicolumn{6}{|c|}{ Tabel 7. Hasil Uji Validitas Berdasarkan Variabel Pemesanan $\left(\mathbf{X}_{4}\right)$} \\
\hline No & \multicolumn{1}{|c|}{ Item Kuisioner } & $\begin{array}{c}\text { Nilai } \\
\mathbf{R}_{\text {hitung }}\end{array}$ & Nilai Sig & $\begin{array}{c}\text { Nilai } \\
\mathbf{R}_{\text {tobel }}\end{array}$ & Keputusan \\
\hline 1 & $\begin{array}{l}\text { Anda dapat mengetahui } \\
\text { posisi driver (order } \\
\text { tracking) }\end{array}$ & 0,906 & 0,000 & 0,1509 & Valid \\
\hline 2 & $\begin{array}{l}\text { Ada personalisasi aplikasi } \\
\text { yang memudahkan } \\
\text { pelanggan (misalnya } \\
\text { history peme }\end{array}$ & 0,910 & 0,000 & 0,1509 & Valid \\
\hline
\end{tabular}

Berdasarkan data tabel di atas, dapat dikatakan bahwa semua item pernyataan pada variabel $\mathrm{X}_{4}$, nilai $\mathrm{r}_{\text {hitung }}>0,159$, atau nilai signifikansi $<0,05$, yang berarti bahwa semua item pernyataan pada variabel $\mathrm{X}_{4}$ adalah valid.

\begin{tabular}{|c|c|c|c|c|c|}
\hline \multicolumn{6}{|c|}{ Tabel 8. Hasil Uji Validitas Berdasarkan Variabel Harga $\left(X_{5}\right)$} \\
\hline No & Item Kuisioner & $\begin{array}{l}\text { Nilai } \\
\mathbf{R}_{\text {hitung }}\end{array}$ & Nilai Sig & $\begin{array}{l}\text { Nilai } \\
\mathrm{R}_{\text {tabel }}\end{array}$ & Keputusan \\
\hline 1 & $\begin{array}{l}\text { Pembayaran dilakukan } \\
\text { dengan mudah }\end{array}$ & 0,768 & 0,000 & 0,1509 & Valid \\
\hline 2 & Harga ojek online murah & 0,865 & 0,000 & 0,1509 & Valid \\
\hline 3 & $\begin{array}{l}\text { Harga ojek sesuai dengan } \\
\text { jarak }\end{array}$ & 0,899 & 0,000 & 0,1509 & Valid \\
\hline \multicolumn{6}{|c|}{ Data SPSS diolah } \\
\hline
\end{tabular}

Berdasarkan data tabel di atas, dapat dikatakan bahwa semua item pernyataan pada variabel $\mathrm{X}_{5}$, nilai $\mathrm{r}_{\text {hitung }}>0,159$, atau nilai signifikansi $<0,05$, yang berarti bahwa semua item pernyataan pada variabel $\mathrm{X}_{5}$ adalah valid.

\begin{tabular}{|c|c|c|c|c|c|}
\hline \multicolumn{6}{|c|}{ Tabel 9. Hasil Uji Validitas Berdasarkan Variabel Tingkat Kepuasan (Y) } \\
\hline No & Item Kuisioner & $\begin{array}{l}\text { Nilai } \\
\mathrm{R}_{\text {hitung }}\end{array}$ & Nilai Sig & $\begin{array}{l}\text { Nilai } \\
\mathbf{R}_{\text {tobel }}\end{array}$ & Keputusan \\
\hline 1 & $\begin{array}{l}\text { Pembayaran dilakukan } \\
\text { dengan mudah }\end{array}$ & 0,899 & 0,000 & 0,1509 & Valid \\
\hline 2 & Harga ojek online murah & 0,870 & 0,000 & 0,1509 & Valid \\
\hline 3 & $\begin{array}{l}\text { Harga ojek sesuai dengan } \\
\text { jarak }\end{array}$ & 0,897 & 0,000 & 0,1509 & Valid \\
\hline \multicolumn{6}{|c|}{ Data SPSS diolah } \\
\hline
\end{tabular}

Berdasarkan data tabel di atas, dapat dikatakan bahwa semua item pernyataan pada variabel Y nilai $\mathrm{r}_{\text {hitung }}>0,159$, atau nilai signifikansi $<$ 0,05 , yang berarti bahwa semua item pernyataan pada variabel $\mathrm{Y}$ adalah valid.

\section{Uji Reliabilitas}

Uji reliabilitas adalah untuk menguji seberapa jauh hasil pengukuran tetap konsisten apabila pengukuran dilakukan berkali-kali terhadap gejala yang sama dengan menggunakan alat pengukur yang sama. Uji reliabilitas untuk penelitian ini menggunakan SPSS 25, untuk 
melihat koefisien angka Alpha Cronbach apakah data reliabel, handal atau tidak.

Untuk melihat apakah pengukuran reliabel atau tidak dapat dilakukan dengan melihat koefisien angka alpha Cronbach. Apabila angka koefisien alpha Cronbach lebih besar dari 0,60 maka dapat disimpulkan bahwa pernyataan kuesioner dianggap reliabel.

\begin{tabular}{|c|c|}
\hline \multicolumn{2}{|c|}{ Tabel 10. Hasil Uji Reliabilitas } \\
Reliability Statistics \\
\hline Cronbach's Alpha & N of Items \\
\hline, 938 & 17 \\
\hline
\end{tabular}

Berdasarkan hasil perhitungan SPSS 25, pada tabel di atas, di dapat nilai Alpha sebesar 0,938 lebih besar dari 0,60. Jadi dapat disimpulkan alat pengukuran melalui kuesioner dapat dikatakan sangat reliabel.

\section{Uji Normalitas}

Untuk melihat apakah variabel bebas dan variabel tidak bebas pada model regresi berdistribusi normal, atau berdistribusi tidak normal, maka dilakukan uji Normalitas dengan pendekatan diagram visual menggunakan SPSS 25.

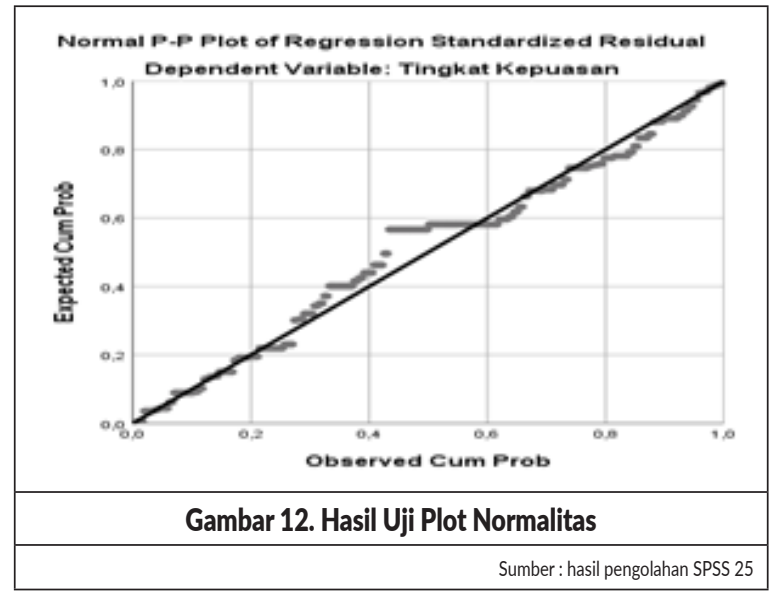

\section{Uji Heterokedastisitas}

Uji heterokedastisitas dilakukan dengan Uji Glejser dimana hasil uji ini dapat dilihat apakah dalam model regresi terjadi ketidaksamaan varian dari suatu residual pengamatan ke pengamatan lain. Adapun ketentuannya terjadi dan tidak terjadi gangguan heteroskedastisitas adalah sebagai berikut :

a. Jika variabel bebas signifikan secara statistik atau memiliki nilai signifikansi (Sig.) $<0,05$, maka terjadi gangguan heteroskedastisitas.

b. Jika variabel bebas tidak signifikan secara statistik atau memiliki nilai signifikansi (Sig.) $>0,05$, maka tidak terjadi gangguan heteroskedastisitas.

\begin{tabular}{|c|c|c|c|c|c|}
\hline \multicolumn{6}{|c|}{ Coefficients $^{a}$} \\
\hline \multirow[b]{2}{*}{ Model } & \multicolumn{2}{|c|}{$\begin{array}{l}\text { Unstandardized } \\
\text { Coefficients }\end{array}$} & \multicolumn{3}{|c|}{ Standardized Coefficients } \\
\hline & B & Std. Error & Beta & $\mathrm{t}$ & Sig. \\
\hline 1 (Constant) &,- 011 & 197 & &,- 054 & 957 \\
\hline Keamanan & 055 & 061 & 119 & 894 &, 373 \\
\hline Pelayananan &,- 016 & 064 &,- 036 &,- 243 &, 809 \\
\hline Waktu &,- 053 & 059 &,- 121 &,- 899 &, 370 \\
\hline Pemesanan & 091 &, 050 & ,234 & 1,817 &, 072 \\
\hline Harga & 016 & 054 & 037 & ,287 &, 774 \\
\hline \multicolumn{6}{|c|}{ a. Dependent Variable: RES2 } \\
\hline \multicolumn{6}{|c|}{ Sumber : hasil pengolahan SPSS 25} \\
\hline
\end{tabular}

Berdasarkan hasil pengujian dengan metode Uji Glejser dengan menggunakan SPSS 25 dapat dilihat bahwa semua nila signifikansi variabel bebas $>0,05$. Ini berarti model regresi tidak ada gangguan heterokedastisitas, sehingga model regresi dapat digunakan sebagai data penelitian.

\section{Uji Multikolonieritas}

Uji Multikolonieritas Pengujian mutlikolinearitas dilakukan untuk meyakini bahwa antar variabel bebas tidak memiliki multikolinearitas atau tidak memiliki korelasi Uji multikolinearitas dapat dilakukan dengan melihat nilai Tolerance Value dan Variance Inflation Factor (VIF). Adapun sebagai prasyarat adalah sebagai berikut :

1) Jika nilai VIF > 10 dan nilai tolerance value $>$ 1 maka terjadi gejala multikoliniearitas

2) Jika nilai $\mathrm{VIF}<10$ dan nilai tolerance value $<$ 1 maka tidak terjadi gejala multikoliniearitas. Berikut adalah hasil pengujian multikolinieritas dilakukan dengan menggunakan SPSS 25 , pada tabel 10 dengan hasil sebagai berikut : 


\begin{tabular}{l|r|r|}
\hline \multicolumn{2}{|c|}{ Tabel 12. Hasil Uji Multikolinearitas } \\
\cline { 2 - 3 } Model & \multicolumn{2}{|c|}{ Collinearity Statistics } \\
\hline 1 (Constant) &, 470 & \multicolumn{1}{c|}{ VIF } \\
\hline Keamanan &, 388 & 2,127 \\
\hline Pelayananan &, 459 & 2,575 \\
\hline Waktu &, 502 & 2,176 \\
\hline Pemesanan &, 499 & 1,991 \\
\hline Harga & \multicolumn{2}{|c|}{ Sumber : hasil pengolahan SPSS 25 } \\
\hline \multicolumn{2}{|c}{} \\
\hline
\end{tabular}

Berdasarkan tabel Uji Multikolinieritas pada tabel 4.2. di atas diperoleh nilai tolerance masing-masing variabel bebas $\mathrm{X}_{1}, \mathrm{X}_{2} . \mathrm{X}_{3}, \mathrm{X}_{4}$, dan $\mathrm{X}_{5}$ dengan hasil kurang dari 1, sementara nilai Variance Inflation Factor (VIF) masing variabel bebas $\mathrm{X}_{1}, \mathrm{X}_{2} . \mathrm{X}_{3}, \mathrm{X}_{4}$, dan $\mathrm{X}_{5}$ mendapatkan hasil kurang dari 10. Dengan demikian model regresi ini tidak ada multikolinearitas.

\section{Korelasi, Koefisien Determinasi, dan Regresi Berganda}

\section{Korelasi}

Untuk melihat kuat lemahnya hubungan dua variabel dapat ditunjukkan oleh nilai Pearson Correlation (R) dimana nilai secara umum dibagi menjadi sbb:

$$
\begin{aligned}
0-0.25 & \rightarrow \text { korelasi sangat lemah } \\
0.25-0.50 & \rightarrow \text { korelasi moderat } \\
0.50-0.75 & \rightarrow \text { korelasi kuat } \\
0.75-1.00 & \rightarrow \text { korelasi sangat kuat }
\end{aligned}
$$

\section{Hipotesis:}

$\mathrm{H}_{0}$ : Tidak ada korelasi yang nyata antara $\mathrm{X}_{1}$ dan $\mathrm{Y}$

$\mathrm{H}_{1}$ : Ada korelasi yang nyata antara $\mathrm{X}_{1}$ dan $\mathrm{Y}$

\section{Dasar Pengambilan Keputusan}

> Jika probalitasnya (nilai sig) $>0.05$ maka $\mathrm{H}_{0}$ tidak ditolak

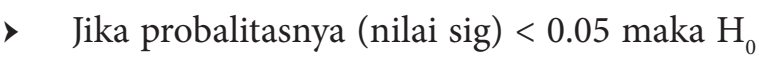
ditolak

\begin{tabular}{|c|c|c|c|c|c|c|c|}
\hline \multicolumn{8}{|c|}{ Tabel 13. Hasil Uji Korelasi } \\
\hline \multicolumn{8}{|c|}{ Correlations } \\
\hline & & $\begin{array}{c}\text { Tingkat } \\
\text { Kepuasan }\end{array}$ & Keamanan & $\begin{array}{l}\text { Pelaya- } \\
\text { nanan }\end{array}$ & Waktu & $\begin{array}{l}\text { Peme- } \\
\text { sanan }\end{array}$ & Harga \\
\hline \multirow{3}{*}{$\begin{array}{l}\text { Tingkat } \\
\text { Kepuas- } \\
\text { an }\end{array}$} & $\begin{array}{l}\text { Pearson } \\
\text { Correlation }\end{array}$ & 1 &, $472^{* *}$ &, $537^{* *}$ &, $470^{* *}$ &, $498^{* *}$ &, $663^{* *}$ \\
\hline & $\begin{array}{l}\text { Sig. } \\
\text { (2-tailed) }\end{array}$ & &, 000 & ,000 & ,000 & ,000 & ,000 \\
\hline & N & 118 & 118 & 118 & 118 & 118 & 118 \\
\hline \multicolumn{8}{|c|}{ **. Correlation is significant at the 0.01 level (2-tailed). } \\
\hline \multicolumn{8}{|c|}{ Sumber : hasil pengolahan SPSS 25} \\
\hline
\end{tabular}

Berdasarkan hasil uji korelasi Pearson dengan menggunakan SPSS di dapat hasil pada tabel di bawah berikut :
Berdasarkan hasil uji korelasi pada tabel di atas, nilai Sig $\mathrm{X}_{1}$ terhadap Y adalah 0.000 , begitu juga dengan nilai Sig $\mathrm{X}_{2}$ terhadap $\mathrm{Y}$ dan juga nilai Sig $\mathrm{X}_{3}, \mathrm{X} 4$, dan $\mathrm{X}_{5}$ terhadap $\mathrm{Y}$. Berdasarkan data tersebut nilai Sig masing-masing $\mathrm{X}_{1}, \mathrm{X}_{2}, \mathrm{X}_{3}, \mathrm{X}_{4}$ dan $\mathrm{X}_{5}$ terhadap $\mathrm{Y}$, lebih kecil dari 0.05 , yang berarti $\mathrm{H}_{\mathrm{O}}$ ditolak. Ini berarti dapat disimpulkan ada hubungan yang nyata masing-masing $\mathrm{X}_{1}, \mathrm{X}_{2}, \mathrm{X}_{3}$, $\mathrm{X}_{4}$, dan $\mathrm{X}_{5}$ terhadap $\mathrm{Y}$.

Berdasarkan koefisien nilai korelasi Pearson, variabel bebas $\mathrm{X}_{1}$ terhadap $\mathrm{Y}$ sebesar 0.472 menunjukkan tingkat hubungan kedua variabel pada tingkat moderat. Koefiesien korelasi variabel bebas $\mathrm{X}_{2}$ terhadap $\mathrm{Y}$ sebesar 0.537 menunjukkan tingkat hubungan kedua variabel pada tingkat kuat. Begitu juga untuk variabel $\mathrm{X}_{3}(0.534)$, dan $\mathrm{X}_{4}$ $(0,663)$ masing-masing terhadap $Y$, menunjukkan tingkat hubungan yang kuat dengan level of significance 0.01 .

\section{Koefisien Determinasi}

Berdasarkan hasil uji koefisien determinasi pada tabel di bawah, diperoleh nilai R-square (koefisien determinasi) sebesar 0,482, menunjukkan bahwa 48,2 persen dari varians $\mathrm{Y}$ dapat dijelaskan oleh perubahan dalam variabel $\mathrm{X}_{1}, \mathrm{X}_{2}$, $\mathrm{X}_{3}, \mathrm{X}_{4}$, dan $\mathrm{X}_{5}$. Sedangkan 51,8 persen sisanya dijelaskan oleh faktor lain di luar model.

\section{Tabel 14. Hasil Uji Koefisien Determinasi}

\begin{tabular}{|c|c|c|c|c|}
\hline \multicolumn{5}{|c|}{ Model Summary } \\
\hline Model & $\mathbf{R}$ & R Square & Adjusted R Square & Std. Error of the Estimate \\
\hline 1 &, $694^{\mathrm{a}}$ &, 482 &, 459 &, 498 \\
\hline \multicolumn{3}{|c|}{ a. Predictors: (Constant), Harga, Keamanan, Pemesanan, Waktu, Pelayananan } \\
\hline \multicolumn{6}{|c|}{ Sumber : pengolahan SPSS 25} \\
\hline
\end{tabular}




\section{Analisis Regresi Berganda}

Pada analisis regresi berganda akan dapat dibuat model regresi berganda berdasarkan perhitungan SPSS 25. Berdasarkan perhitungan SPSS 25, diperoleh tabel koefisien di bawah :

\begin{tabular}{|c|c|c|c|c|c|}
\hline \multicolumn{6}{|c|}{ Tabel 15. Tabel Coeficients $\mathrm{Re}$} \\
\hline \\
\hline \multirow[b]{2}{*}{ Model } & \multicolumn{2}{|c|}{$\begin{array}{l}\text { Unstandardized } \\
\text { Coefficients }\end{array}$} & \multicolumn{3}{|c|}{ Standardized Coefficients } \\
\hline & B & Std. Error & Beta & $\mathrm{t}$ & Sig. \\
\hline 1 (Constant) & ,782 &, 315 & & 2,484 & 015 \\
\hline Keamanan & ,194 & 101 & ,192 & 1,921 & 057 \\
\hline Pelayananan & ,099 & 103 & 104 & ,965 & ,337 \\
\hline Waktu & 027 & 094 & 029 & 289 &, 773 \\
\hline Pemesanan & 085 & 082 &, 100 & 1,030 & 305 \\
\hline Harga & ,378 & 090 &, 412 & 4,198 &, 000 \\
\hline \multicolumn{6}{|c|}{ a. Dependent Variable: Tingkat Kepuasan } \\
\hline \multicolumn{6}{|c|}{ Sumber : hasil pengolahan SPSS 25} \\
\hline
\end{tabular}

Dari tabel perhitungan SPSS 25 di atas, dapat diperoleh bentuk persamaan regresi linear berganda sebagai berikut :

$\mathrm{Y}=0.782+0.194 \mathrm{X}_{1}+0.099 \mathrm{X} 2+0.027 \mathrm{X}_{3}$ $+0.085 \mathrm{X}_{4}+0,378 \mathrm{X}_{5}$

Dari model persamaan regresi linear berganda di atas, variabel bebas $\mathrm{X}_{1}, \mathrm{X}_{2}, \mathrm{X}_{3}, \mathrm{X}_{4}$, dan $\mathrm{X}_{5}$ mempunyai pengaruh yang positif terhadap variabel tidak bebas Y. Artinya peningkatan pada nilai X1, X2, X3, X4 dan X5 akan meningkatkan variabel tidak bebas $\mathrm{Y}$.

\section{Pengujian Hipotesis}

\section{Uji t (Parsial)}

Uji t dimaksudkan untuk menguji apakah variabel independen secara parsial berpengaruh signifikan terhadap variabel dependen.

Hipotesis:

$\mathrm{H}_{0}$ : variabel bebas secara parsial tidak berpengaruh signifikan terhadap variabel tidak bebas

$H_{1}$ : variabel bebas secara parsial berpengaruh signifikan terhadap variabel tidak bebas

Dasar Pengambilan Keputusan

> Jika probabilitasnya (nilai sig) $>0.05$ atau $\mathrm{t}_{\text {tabel }}<\mathrm{t}_{\text {hitung }}<\mathrm{t}_{\text {tabel }}$ maka $\mathrm{H}_{0}$ tidak ditolak

> Jika probabilitasnya (nilai sig) $<0.05$ atau $\mathrm{t}_{\text {hitung }}<-\mathrm{t}_{\text {tabel }}$ atau $\mathrm{t}_{\text {hitung }}>\mathrm{t}_{\text {tabel }}$ maka $\mathrm{H}_{0}$ ditolak, diterima $\mathrm{H}_{1}$.

\section{Keputusan:}

1. Pada tabel coeficient hasil regresi berganda di atas nilai sig variabel $X_{1}=0.057>0.05$ sehingga $\mathrm{H}_{0}$ tidak ditolak, yang berarti variabel independen $\left(\mathrm{X}_{1}\right)$ ini secara parsial tidak berpengaruh positif dan signifikan terhadap variabel Y. Faktor keamanan dan kenyamanan di dalam mengggunakan Ojek Online tidak berpengaruh signifikan terhadap tingkat kepuasan pelanggan.

2. Pada tabel coeficient hasil regresi berganda di atas nilai sig variabel $\mathrm{X}_{2}=0.337>0.05$ sehingga $\mathrm{H}_{0}$ tidak ditolak, yang berarti variabel independen $\left(\mathrm{X}_{2}\right)$ ini secara parsial tidak berpengaruh positif dan signifikan terhadap variabel Y. Faktor pelayanan di dalam mengggunakan Ojek Online tidak berpengaruh signifikan terhadap tingkat kepuasan pelanggan.

3. Pada tabel coeficient hasil regresi berganda di atas nilai sig variabel $\mathrm{X}_{3}=0.773>0.05$ sehingga $\mathrm{H}_{0}$ tidak ditolak, yang berarti variabel independen $\left(\mathrm{X}_{3}\right)$ ini secara parsial tidak berpengaruh positif dan signifikan terhadap variabel Y. Faktor ketepatan waktu di dalam mengggunakan Ojek Online tidak berpengaruh signifikan terhadap tingkat kepuasan pelanggan.

4. Pada tabel coeficient hasil regresi berganda di atas nilai sig variabel $\mathrm{X}_{4}=0.305>0.05$ sehingga $\mathrm{H}_{0}$ tidak ditolak, yang berarti variabel independen $\left(\mathrm{X}_{4}\right)$ ini secara parsial tidak berpengaruh positif dan signifikan terhadap variabel Y. Faktor kemudahan pemesanan di dalam mengggunakan Ojek Online tidak berpengaruh signifikan terhadap tingkat kepuasan pelanggan.

5. Pada tabel coeficient hasil regresi berganda di atas nilai sig variabel $\mathrm{X}_{5}=0.000<0.05$ sehingga $\mathrm{H}_{0}$ ditolak dan $\mathrm{H}_{1}$ diterima, yang berarti variabel independen $\left(\mathrm{X}_{5}\right)$ ini secara parsial berpengaruh positif dan signifikan terhadap variabel Y. Faktor kesesuaian harga di dalam mengggunakan Ojek Online berpengaruh signifikan terhadap tingkat kepuasan pelanggan. 


\section{Uji F (Simultan)}

\begin{tabular}{|c|c|c|c|c|c|c|}
\hline & & Tabel 16 & Hasil & & & \\
\hline & & & & & & \\
\hline Model & & $\begin{array}{l}\text { Sum of } \\
\text { Squares }\end{array}$ & df & $\begin{array}{l}\text { Mean } \\
\text { Square }\end{array}$ & $\mathrm{F}$ & Sig. \\
\hline 1 & Regression & 24,888 & 5 & 4,978 & 22,123 & $.000^{\circ}$ \\
\hline & Residual & 24,975 & 111 & 225 & & \\
\hline & Total & 49,863 & 116 & & & \\
\hline $\begin{array}{l}\text { a. Dep } \\
\text { b. Prec }\end{array}$ & $\begin{array}{l}\text { ent Variable } \\
\text { ors: (Constan }\end{array}$ & $\begin{array}{l}\text { t Kepuasar } \\
\text { a, Keaman }\end{array}$ & 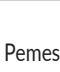 & Wat & 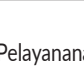 & \\
\hline & & & & Sumber: & asil pengola & SPSS 25 \\
\hline
\end{tabular}

Uji F dimaksudkan untuk menguji apakah variabel-variabel independen secara bersamasama berpengaruh signifikan terhadap variabel dependen.

\section{Hipotesis:}

$\mathrm{H}_{0}$ : variabel-variabel independen secara bersama-sama tidak berpengaruh signifikan terhadap variabel dependen

H1 : variabel-variabel independen secara bersama-sama berpengaruh signifikan terhadap variabel dependen

Dasar Pengambilan Keputusan

> Jika probabilitasnya (nilai sig) $>0.05$ atau $\mathrm{F}_{\text {hitung }}<\mathrm{F}_{\text {tabel }}$ maka $\mathrm{H}_{0}$ tidak ditolak

> Jika probabilitasnya (nilai sig) $<0.05$ atau $\mathrm{F}_{\text {hitung }}>\mathrm{F}_{\text {tabel }}$ maka $\mathrm{H}_{0}$ ditolak

Keputusan:

Pada tabel di atas nilai sig $=0.000<0.05$, sehingga $\mathrm{H}_{0}$ ditolak, yang berarti variabel-variabel independen $\left(\mathrm{X}_{1}, \mathrm{X}_{2}, \mathrm{X}_{3}, \mathrm{X}_{4}, \mathrm{X}_{5}\right)$ secara bersama-sama berpengaruh signifikan terhadap variabel dependen (Y). Faktor-faktor keamanan dan kenyamanan $\left(\mathrm{X}_{1}\right)$, pelayanan $\left(\mathrm{X}_{2}\right)$, ketepatan waktu $\left(\mathrm{X}_{3}\right)$, kemudahan pemesanan $\left(\mathrm{X}_{4}\right)$, dan kesesuaian harga $\left(\mathrm{X}_{5}\right)$, secara bersama-sama mempunyai pengaruh yang signifikan terhadap tingkat kepuasan pelanggan $(\mathrm{Y})$.

\section{SIMPULAN}

\section{Kesimpulan}

Berdasarkan hasil pembahasan analisis faktor-faktor yang mempengaruhi tingkat kepuasan pelanggan penggunaan ojek online, dapat disimpulkan beberapa hal, yaitu sebagai berikut:

1. Berdasarkan hubungannya (korelasi) :

a. Faktor keamanan dan kenyamanan mempunyai korelasi yang moderat terhadap tingkat kepuasan pengguna ojek online.

b. Faktor tingkat pelayanan mempunyai korelasi yang kuat terhadap tingkat kepuasan pengguna ojek online.

c. Faktor ketepatan waktu mempunyai korelasi yang moderat terhadap tingkat kepuasan pengguna ojek online.

d. Faktor kemudahan pemesanan mempunyai korelasi yang moderat terhadap tingkat kepuasan pengguna ojek online.

e. Faktor kesesuaian harga mempunyai korelasi yang kuat terhadap tingkat kepuasan pengguna ojek online.

2. Faktor-faktor yang mempengaruhi tingkat kepuasan layanan ojek online dengan mengukur pengaruh faktor tersebut terhadap tingkat kepuasan pengguna ojek online.

a. Berdasarkan Uji t, diketahui bahwa faktor yang mempengaruhi Tingkat Kepuasan pengguna Gojek Online secara signifikan hanya faktor kesesuaian harga $\left(\mathrm{X}_{5}\right)$. Sementara faktor lainnya secara sendiri-sendiri tidak mempengaruhi secara signifikan terhadap tingkat kepuasan pengguna ojek online.

b. Berdasarkan Uji F, diketahui bahwa secara simultan faktor-faktor keamanan dan kenyamanan, pelayanan, ketepatan waktu, kemudahan pemesanan, dan kesesuaian harga secara bersama-sama berpengaruh signifikan terhadap tingkat kepuasan pengguna ojek online.

\section{Saran}

Perlu dikaji dan diidentifikasi lagi lebih dalam dan lebih tajam terkait variabel faktorfaktor yang mempengaruhi tingkat kepuasan pelanggan, mengingat berdasarkan koefisien determinasi, model regresi hasil perhitungan nilai $R$-square (koefisien determinasi) sebesar 0,482, menunjukkan hanya sebesar 48,2 persen dari varian $\mathrm{Y}$ dapat dijelaskan oleh perubahan dalam variabel $\mathrm{X}_{1}, \mathrm{X}_{2}, \mathrm{X}_{3}, \mathrm{X}_{4}$, dan $\mathrm{X}_{5}$ pada model regresi, sedangkan 51,8 persen sisanya dijelaskan oleh faktor lain di luar model. 


\section{DAFTAR PUSTAKA}

Allan Afuah, Christopher L Tucci, Internet Business Model and Strategies: Text and Cases, Second Edition, Mc Graw Hill, New York.

Bambang Juanda, 2009, Ekonometrika, Pemodelan dan Pendugaan, IPB Press, Bogor.

David S Evan, Andrei Hagiu, Richard Schamalensee, 2006, Invisible Engines, How Software Platform Drive Innovation and Transform Industries, The MIT Press, Cambridge, Massachussets, London England.

Dwi Priyatno. 2008, Belajar SPSS (Untuk Analisis Data dan Uji Statistik), Mediakom, Yogyakarta

Fredy Rangkuti, 2013, Customer Service Satisfaction \& Call Center Berdasarkan ISO 9001, PT Gramedia Pustaka Utama, Kompas Gramedia, Jakarta.

Ghozali, Imam, 2011, Aplikasi Analisis Multivariate Dengan Program SPSS, Semarang: Badan Penerbit Universitas Diponegoro.

Ghozali, Imam, 2006, Aplikasi Analisis Multivariate Dengan Program SPSS, Cetakan Keempat. Semarang: Badan Penerbit Universitas Diponegoro.

Hal R Varian, 2010, Intermediate Micro Economic A Modern Approach, Eight Edition, W.W Norton And Company, New York.

http://ekonomi.metrotvnews.com/analisaekonomi/ob3VJ1mN-mengukur-tarif-ojekonline, di akses tgl 26/09/2018.

https://www.galena.co.id/q/bagaimana-gojekmenghasilkan-keuntungan, di akses tgl 06 Maret 2019.

h t t p : / / w w w.t ribun new s. co m / section/2019/02/18/4-unicorn-di-indonesiayang-perlu-kamu-tahu-sempat-jadi-topikbahasan-di-debat-pilpres-2019?page $=2, \quad$ di akses tgl 04 Maret 2019.

Husein, Umar, 2008, Metode Penelitian Untuk Skripsi dan Tesis Bisnis.Jakarta, PT Rajagrafindo Persada.

Jusman Syafii Djamal, 2015, Notes On Strategy and Techno Economy, Kemana Kita Hendak Melangkah?, Diandra Kreatif, Rethinking, Indonesia.

Junic Kim, 2015, Thesis Doctor of Philosophy,
The Platform Business Model and Strategy: A Dynamic Analysis of the Value Chain and Platform Business, Manchester Business School, Manchester Institute of Innovation Research.

Michael E Porter, 2001, Strategy and the Internet, Harvard Business Review.

Multifiah, 2011, Teori Ekonomi Mikro, UB Press, Malang Indonesia.

Murat Uenlue, 2017, https://www.innovationtactics.com/platform-business-modelcomplete-guide/, di akses tgl 04 Maret 2019.

Murat Uenlue, 2017, https://www.innovationtactics.com/business-model-canvasuber/, di akses tgl 04 Maret 2019.

Nugroho, Bhuono Agung. Strategi Jitu Memilih Metode Statistik Penelitian dengan SPSS, Yogyakarta: Andi, 2005.

Osterwarder A, Pigneur Y, An e-Business Model Ontology for Modeling e-Business, 15th Bled Electronic Commerce Conference, Bled, Slovenia, June 17 - 19, 2002.

Osterwarder A, Pigneur Y, Business Model Generation, Self Published, 2009.

Phil Simon, 2014, The Age Of The Platform, Edisi Revisi, PT Elex Media Komputindo, Kompas Gramedia, Jakarta.

Sawidji Widoatmodjo, 2005, New Business Model, Strategi Ampuh Memenangi Bisnis di Abad ke-21, PT Media Elex Media Komputindo, Gramedia, Jakarta.

Sawidji Widoatmodjo, 2016, New Business Model In Digital Age, PT Meida Elex Media Komputindo, Gramedia, Jakarta.

Sekaran Uma, 2014, Metodologi Penelitian untuk Bisnis, Jakarta: Salemba Empat.

Sujarweni, V.W, 2015, Statistik Untuk Bisnis dan Ekonomi, Yogyakarta: Pustaka Baru Press.

Sugiyono, 2010, Metode Penelitian Pendidikan Pendekatan Kuantitatif, kualitatif, dan R\&D, Alfabeta, Bandung.

Sudarmanto, R.Gunawan, 2005, Analisis Regresi Linear Ganda dengan SPSS, Graha Ilmu. Yogyakarta. 